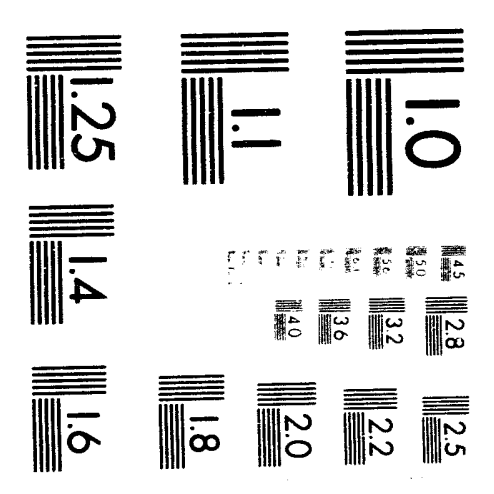



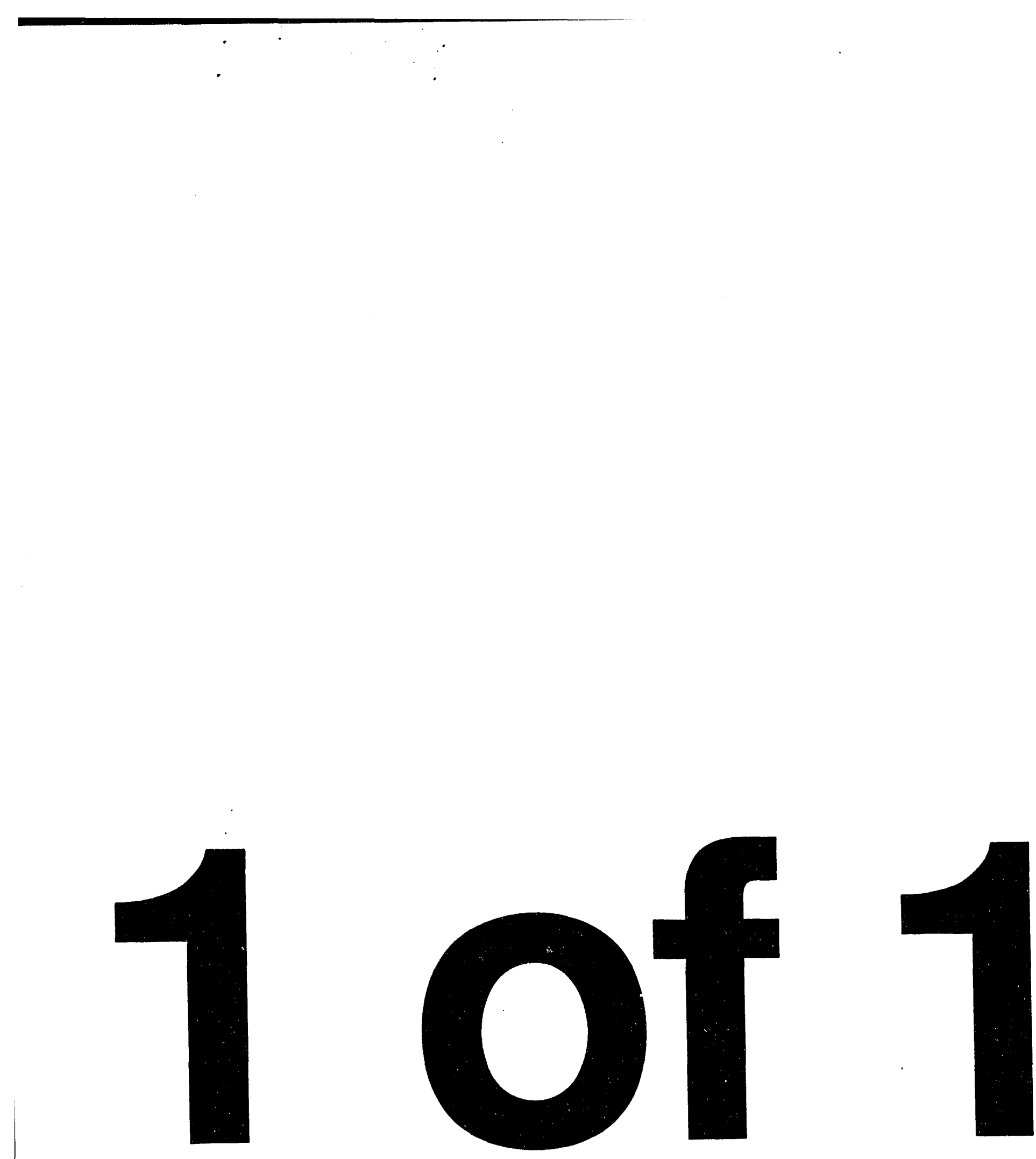


\title{
Thermal Performance of Residential Duct Systems in Basements
}

\author{
Burke Treidler and Mark Modera \\ Energy and Environment Division \\ Lawrence Berkeley Laboratory \\ University of California \\ Berkeley, CA 94720
}

February 1994

This work was supported by the Assistant Secretary for Conservation and Renewable Energy, Office of Building Energy Research and Development, Building Systems Division of the U.S. Department of Energy under Contract No. DE-AC03-76SF00098.

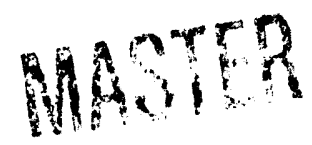




\title{
Thermal Performance of Residential Duct Systems in Basements
}

\author{
Burke Treidler and Mark Modera \\ Energy and Environment Division \\ Lawrence Berkeley Laboratory \\ University of California \\ Berkeley, CA 94720
}

February 10, 1994

\begin{abstract}
There are many unanswered questions about the typical effects of duct system operation on the infiltration rates and energy usage of single-family residences with HVAC systems in their basements. In this paper, results from preliminary field studies and computer simulations are used to examine the potential for improvements in efficiency of air distribution systems in such houses. The field studies comprise thermal and flow measurements on four houses in Maryland. The houses were found to have significant envelope leakage, duct leakage, and duct conduction losses. Simulations of a basement house, the characteristics of which were chosen from the measured houses, were performed to assess the energy savings potential for basement house. The simulations estimate that a nine percent reduction in space conditioning energy use is obtained by sealing eighty percent of the duct leaks and insulating ducts to an R-value of 0.88 ${ }^{\circ} \mathrm{C} \cdot \mathrm{m}^{2} / \mathrm{W}\left(5^{\circ} \mathrm{F} \cdot \mathrm{ft}^{2} \cdot \mathrm{h} / \mathrm{BTU}\right)$ where they are exposed in the basement. To determine the maximu,n possible reduction in energy use, simulations were run with all ducts insulated to $17.6^{\circ} \mathrm{C} \cdot \mathrm{m}^{2} / \mathrm{W}\left(100^{\circ} \mathrm{F} \cdot \mathrm{ft}^{2} \cdot \mathrm{h} / \mathrm{BTU}\right)$ and with no duct leakage. A reduction of energy use by $14 \%$ is obtained by using perfect ducts instead of normal ducts.
\end{abstract}

\subsection{Introduction}

Approximately $50 \%$ of the households in the U.S have forced air central furnaces (DOE 1987). This implies that there are approximately one and a half million kilometers of residential ducts in the U.S. (ibid.). Because of their prevalence, residential duct systems have been a topic of much study. A review of the literature shows the interest of groups such as the Gas Research Institute (Orlando, 1980), the National Bureau of Standards and Princeton University (Grot and Harrje, 1981), and Brookhaven National Laboratory (BNL, 1984). In addition, there was Special Project 43 of the American Society of Heating, Refrigerating, and Air Conditioning Engineers, Inc. (Jacob et al., 1986; 
Jacob et al., 1986a; Locklin et al., 1987). All of these groups reached the conclusion that air distribution systems have significant impacts on residential heating and cooling energy use.

Another attention getting aspect of air distribution systems is their effect on air infiltration. Several studies have shown large changes in air infiltration of residences due to the air distribution system. Researchers in Florida found that turning on the HVAC system fan tripled the air infiltration rate. Closing the doors when the fan was on produced a further tripling of the infiltration rate (Cummings, 1989). In addition, researchers in Tennessee showed an $81 \%$ averagc increase in infiltration for 31 houses (Gammage, 1986). This increase in infiltration, and the initial tripling in Florida, were attributed to leaks in the duct systems of the houses. The second tripling in the Florida houses was attributed to inadequate return air pathways around closed doors.

The studies referred to above did not deal with the differences between basement and crawlspaces houses. All of the studies, except for those associated with the SP43 project and the Grot/Harrje study, dealt with houses where HVAC systems are located in garages, crawlspaces, or attics. These spaces are generally well vented and any energy lost by the duct system is not recovered. Basements are usually neither vented to the outside nor fully conditioned; they are partly conditioned. ${ }^{1}$

The methods used for the field measurements presented in this paper have previously been used in a measurement program of 31 houses in California. A similar simulation methodology has also been used for simulations of houses in California climates (Modera et al., 1991; Modera and Jansky, 1992).

The field results presented here were collected by GEOMET Technologies, Inc. (see GEOMET, 1992) in cooperation with researchers at Lawrence Berkeley Laboratory. Measurements were made of the envelope leakage, duct leakage, duct conduction losses, infiltration, and various pressure differences. The results show a large potential for energy savings in these houses. Of particular interest is the predominance of uninsulated and unsealed ducts in all of the houses which result in significant conduction losses from ducts even on mild spring days.

The simulation results presented are for a two-story basement house located in Atlanta, GA, Minneapolis, MN, and Washington, D.C. The HVAC system and most of the duct work is located in the basement. The effects of insulation and sealing are investigated. Results are presented for infiltration, the overall distribution system efficiency, $\eta_{\text {dist }}$, and the components of $\eta_{\text {dist }}$. It is found that an eight percentage point improvement in $\eta_{\text {dist }}$ may be obtained by sealing $80 \%$ of the duct leaks and insulating the ducts in the basement to an $\mathrm{R}$-value of $0.88^{\circ} \mathrm{C} \cdot \mathrm{m}^{2} / \mathrm{W}\left(5^{\circ} \mathrm{F} \cdot \mathrm{ft}^{2} \cdot \mathrm{h} / \mathrm{BTU}\right)$. A simulation for Washington, D.C., showed that a further six percentage point improvement in $\eta_{\text {dist }}$ may be obtained by

1. A reasonable fraction of crawlspaces are unvented and therefore also merit further investigation. 
sealing $100 \%$ of the duct leaks and insulating all ducts to an $\mathrm{R}$-value of $17.6{ }^{\circ} \mathrm{C} \cdot \mathrm{m}^{2} / \mathrm{W}(100$ $\left.{ }^{\circ} \mathrm{F} \cdot \mathrm{ft}^{2} \cdot \mathrm{h} / \mathrm{BTU}\right)$.

\subsection{Field Results}

Results are presented here from field measurements in 4 houses with basements in the Baltimore, MD area. Although this sample size is quite small, it provides direction for future studies and data that can be used in combination with computer simulations. The results for these houses will be compared to those found in a much larger study for residences with HVAC systems in their attics and garages (Modera et al., 1991). The leakage measurements will also be compared to the results of Nelson et al. (1993) for eight randomly selected new houses in the Minneapolis, MN area.

In comparing leakage data between different houses it is important to note the position $6:$ the basement door. If the basement door is open, then the basement is part of the conditioned space and there is no buffer zone. All ducts are then within the conditioned space. If the basement door is closed, then the basement acts as a buffer zone, and some of the energy lost to it will be lost to outside.

The field measurements were made by GEOMET Technologies, Inc. One of the purposes of the study was to evaluate a protocol for evaluating thermal distribution systems in houses with basements. The results of the measurements and a copy of the protocol can be found in GEOMET Report NO. IE-2598 (1992).

\subsection{House Descriptions}

Relevant data about the houses are presented in Table 1. Letters are used to distinguish individual houses. An interesting point from Table 1 is the prevalence of uninsulated and unsealed duct systems in unconditioned or partly conditioned spaces. Because of this, significant energy losses occur in ducts. An additional point of concern is the location of ducts in exterior walls in House B. Because a duct placed in a wall stud cavity allows little insulation to be placed in that cavity, the duct is effectively passing through an uninsulated exterior wall. This represents a potentially large energy loss both directly from the duct to outside and from the house to outside when the HVAC fan is off.

\subsection{Leakage Results}

The envelope leakiness was measured with a blower door using a modified version of ASTM Standard E779 (1987). The duct leakiness was measured with a direct duct pressurization system (DPSS) and a blower door. The DPSS was used for three duct leakage measurements: 1) with the blower door off and the basement door open; 2) with the blower door on, the door to the basement closed, and the basement windows open; and 3) with the blower door on, the basement door open, and 
TABLE 1. Description of houses, HVAC systems, and duct systems.

\begin{tabular}{|c|c|c|c|c|}
\hline Character istic & $\mathbf{A}$ & $\mathbf{B}$ & $\mathbf{C}$ & D \\
\hline $\begin{array}{l}\text { year of construc- } \\
\text { tion }\end{array}$ & 1970 & 1978 & 1988 & 1982 \\
\hline configuration & $\begin{array}{l}2 \text { story over base- } \\
\text { ment }(70 \%) \text { and } \\
\text { crawlspace }(30 \%)\end{array}$ & $\begin{array}{l}\text { 2-story over basement } \\
(70 \%) \text { and crawlspace } \\
(30 \%)\end{array}$ & 2 story over basement & $\begin{array}{l}\text { 1 story over basement } \\
(50 \%) \text { and garage }(50 \%)\end{array}$ \\
\hline floor area (sq. ft) & 2400 & 2130 & 2868 & 1400 \\
\hline furnace location & basement & basement & basement & basement \\
\hline $\begin{array}{l}\text { basement condi- } \\
\text { toned? }\end{array}$ & no & no & $\begin{array}{l}\text { yes ( } 2 \text { registers, but not } \\
\text { fully conditioned) }\end{array}$ & $\begin{array}{l}\text { yes ( } 2 \text { registers, but not } \\
\text { fully conditioned) }\end{array}$ \\
\hline duct type & $\begin{array}{l}\text { sheet metal, ructan- } \\
\text { gular }\end{array}$ & $\begin{array}{l}\text { sheet metal, rectangular } \\
\text { with some round } \\
\text { branches }\end{array}$ & $\begin{array}{l}\text { sheet metal, rectangu'ar } \\
\text { trunk and return, oval } \\
\text { risers }\end{array}$ & $\begin{array}{l}\text { sheet metal and duct- } \\
\text { board, rectangular and } \\
\text { round }\end{array}$ \\
\hline duct insulation & $\begin{array}{l}\text { branches in crawl- } \\
\text { space + part of main } \\
\text { trunk }\end{array}$ & $\begin{array}{l}\text { none, except ducts cov- } \\
\text { ered by basement ceiling } \\
\text { insulation }\end{array}$ & none & none \\
\hline trunk duct location & $\begin{array}{l}\text { basement and crawl- } \\
\text { space }\end{array}$ & $\begin{array}{l}\text { basement and crawl- } \\
\text { space }\end{array}$ & basement & basement and garage \\
\hline $\begin{array}{l}\text { branch duct loca- } \\
\text { tion }\end{array}$ & $\begin{array}{l}\text { interior partitions, } \\
\text { attic, and crawlspace }\end{array}$ & $\begin{array}{l}\text { basement, crawlspace, } \\
\text { interior partitions, and } \\
\text { exterior wall }\end{array}$ & $\begin{array}{l}\text { basement, interior parti- } \\
\text { tions }\end{array}$ & basement and garage \\
\hline duct sealing & none & none & some duct tape & $\begin{array}{l}\text { none, except tape on } \\
\text { air-handler-duct connec- } \\
\text { tion }\end{array}$ \\
\hline $\begin{array}{l}\text { number of return } \\
\text { registers }\end{array}$ & 2 & 12 & 2 & 2 \\
\hline Heating System & gas furnace & $\begin{array}{l}\text { beat pump and electrical } \\
\text { resistance heating }\end{array}$ & $\begin{array}{l}\text { heat pump and electrical } \\
\text { resistance beating }\end{array}$ & $\begin{array}{l}\text { heat pump and electrical } \\
\text { resistance heating }\end{array}$ \\
\hline Door undercuts & $1.6 \mathrm{~cm}$ & $0.9 \mathrm{~cm}$ & $1.1 \mathrm{~cm}$ & $0.9 \mathrm{~cm}$ \\
\hline
\end{tabular}

the windows in the basement closed. In the tests with the blower door on, the conditioned space and duct system pressures were kept equal.

The results of the measurements were used to estimate leakage area from the ducts to the conditioned space, the exterior, and the basement. The leakage estimates are presented in Table 2. Equivalent leakage area, or ELA, considers leakage from the house to the basement, attic, and outside. The oldest house, A, shows a much larger total envelope leakage area. As a consequence of this, the specific ELA, which is the ELA in $\mathrm{cm}^{2}$ per $\mathrm{m}^{2}$ of floor area, is three times higher for house $\mathrm{A}$, than for houses $B$ and D. From the results for houses B and C, a typical specific ELA for these building envelope seems to be $2-3 \mathrm{~cm}^{2} / \mathrm{m}^{2}$. This is smaller than the average of $5.4 \mathrm{~cm}^{2} / \mathrm{m}^{2}$ found in Sherman et al. (1984) for 277 houses built between 1961 and 1983 in the United States. It is also smaller than was found in a previous study of residences in California (Modera et al., 1991). In that study, which was for slab-on-grade and crawlspace residences, the specific ELA was found to be 6.0 and $3.9 \mathrm{~cm}^{2} / \mathrm{m}^{2}$ for pre-1980 and post-1979 houses, respectively. The difference between the Maryland and California data may be due to the larger surface area for a given floor space in the typically one-story California houses, but may also be due to differences in construction practices. The floor of the second story and 
the ceiling of the first story do not leak to outside. In all but House D, the ELA between ducts and the conditioned space is very small relative to the total ELA for the house.

For total duct leakage area, all the houses are comparable. The specific leakage areas for the supply ducts have a small range of $0.9-1.1 \mathrm{~cm} / \mathrm{m}^{2}$. The return ducts have a range of specific leakage areas of $0.5-1.3 \mathrm{~cm}^{2} / \mathrm{m}^{2}$. A reasonable estimate for duct leaks is $1 \mathrm{~cm}^{2}$ per $\mathrm{m}^{2}$ of floor area for the return and supply duct systems individually. The results show that all the duct systems in this study leak primarily to the basement. The percentage of total ELA to the basement ranges from 52 to $96 \%$ with the supply and return ducts both averaging $70 \%$. There is no pattern to the division of the remaining leakage area to inside and outside. Much of the duct leakage to "outside" actually gues to the attic via stud wall cavities. In Modera et al. (1991), specific leakage areas of 0.4 and $0.5 \mathrm{~cm}^{2} / \mathrm{m}^{2}$ were found for the supply and return ducts, respectively. The lower specific leakage area could be due to the use of flexible ducts with "sealed" joints in California. The houses in this study had sheet metal ducts except for some made of ductboard in House D The lower specific leakage area could also be due to smaller duct systems per unit floor area in California.

TABLE 2. Envelope and duct leakage data ${ }^{a}$

\begin{tabular}{|c|c|c|c|c|c|c|c|c|c|}
\hline \multirow[b]{2}{*}{ Characteristic } & \multirow[b]{2}{*}{ Type } & \multicolumn{8}{|c|}{ GEOMET House } \\
\hline & & $\mathbf{A}$ & & $\mathbf{B}$ & & $\mathbf{C}$ & & $\mathbf{D}$ & \\
\hline \multirow{2}{*}{$\begin{array}{l}\text { Envelope Leakage Area } \\
\left(\mathrm{cm}^{2} @ 4 \mathrm{~Pa}\right)\end{array}$} & to attic, basement, and outside ${ }^{b}$ & 1534 & & 576 & & & & 297 & \\
\hline & specific $\left(\mathrm{cm}^{2} / \mathrm{m}^{2}\right)$ & 7.0 & & 2.9 & & & & 2.3 & \\
\hline \multirow{5}{*}{$\begin{array}{l}\text { Supply-Duct Leakage } \\
\text { Area }\left(\mathrm{cm}^{2} @ 4 \mathrm{~Pa}\right)\end{array}$} & to basement & 199 & $(78 \%)$ & 170 & $(83 \%)$ & 120 & $(52 \%)$ & 79 & $(66 \%)$ \\
\hline & to inside & & $(2 \%)$ & 0 & $(0 \%)$ & 71 & $(30 \%)$ & 18 & $(15 \%)$ \\
\hline & to outside & 52 & $(20 \%)$ & 34 & $(17 \%)$ & 41 & $(18 \%)$ & 23 & $(19 \%)$ \\
\hline & total & 256 & & 203 & & 232 & & 120 & \\
\hline & total specific $\left(\mathrm{cm}^{2} / \mathrm{m}^{2}\right)$ & 1.1 & & 1.0 & & 0.9 & & 0.9 & \\
\hline \multirow{5}{*}{$\begin{array}{l}\text { Return Duct Leakage } \\
\text { Area }\left(\mathrm{cm}^{2} @ 4 \mathrm{~Pa}\right)\end{array}$} & to basement & 63 & $(60 \%)$ & 173 & $(68 \%)$ & 166 & $(58 \%)$ & 108 & $(96 \%)$ \\
\hline & to inside & 19 & $(18 \%)$ & 2 & $(1 \%)$ & 90 & $(31 \%)$ & 5 & $(4 \%)$ \\
\hline & to outside & 23 & $(22 \%)$ & 79 & $(31 \%)$ & 31 & $(11 \%)$ & 0 & $(0 \%)$ \\
\hline & total & 104 & & 253 & & 288 & & 113 & \\
\hline & total specific $\left(\mathrm{cm}^{2} / \mathrm{m}^{2}\right)$ & 0.5 & & 1.3 & & 0.9 & & 0.9 & \\
\hline \multirow[t]{2}{*}{$\%$ of Total duct leakage } & supply duct ELA @ $4 \mathrm{~Pa}$ & & $71 \%$ & & $45 \%$ & & $45 \%$ & & $52 \%$ \\
\hline & return duct ELA @ $4 \mathrm{~Pa}$ & & $29 \%$ & & $55 \%$ & & $55 \%$ & & $48 \%$ \\
\hline
\end{tabular}

a percentages are of total value

$b_{b}$ asement windows open

In another study, Nelson et al. (1993) made measurements in eight new basement houses and found an average envelope and duct ELA's of $620 \mathrm{~cm}^{2}$ and $780 \mathrm{~cm}^{2}$, respectively. The specific ELA's are 2.2 and $2.8 \mathrm{~cm}^{2} / \mathrm{m}^{2}$ for the envelope and ducts, respectively. They measured ELA's using a blower door with the basement door open. The values therefore represent leakage from the house and 
basement to the attic and outside. The average envelope and duct ELA's for the houses in the current study are $800 \mathrm{~cm}^{2}$ and $390 \mathrm{~cm}^{2}$, respectively. The envelope ELA's for the two studies are similar. However, there is a large difference between this study and Nelson et al. for duct ELA. Nelson et al. find an average duct leakage 50\% greater than that found in the current project. One possible reason for this is that the houses in Minneapolis all have multiple return registers. Only House B in the current study has more than 2 returns.

\subsection{Duct operating pressures results}

The pressure differences between ducts and their surrounding areas are shown in Table 3 . The wide range of operating pressures for the ducts is noticeable. Return plenum pressures vary from -42 to $-200 \mathrm{~Pa}$. The supply duct and supply plenum pressures also vary by a factor of 3 . This raises doubts as to the usefulness of an ELA at $4 \mathrm{~Pa}$, both because of the wide range of pressures, and the assumption used to calculate ELA's that flow varies with the square root of the driving pressure. The pressures found in these houses also vary tremendously from those found in the Modera et al. (1991), particularly for the supply plenum and ducts. In that study, average pressures of $46,29,-88$, and $-57 \mathrm{~Pa}$ were found for the supply plenum, average supply duct, return plenum, and average return duct, respectively.

TABLE 3. Pressure differences during HVAC system fan operation.

\begin{tabular}{|l|l|l|l|l|}
\hline & \multicolumn{3}{|l|}{ GEOMET House } \\
Location & A & B & C & D \\
\hline Supply Plenum (Pa) & 6 & 27 & 9 & 17 \\
\hline Supply Duct Average (1) & 5 & 17 & 6 & 13 \\
\hline Return Plenum (Pa) & -80 & -201 & -42 & -103 \\
\hline Return Duct Average (Pa) & -52 & -103 & -23 & -64 \\
\hline
\end{tabular}

\subsection{Infiltration results}

Air infiltration rates were measured using a tracer-gas technique. The method used was to open all interior doors and turn on the furnace fan. SF $_{6}$ was then released into the return register for 5 minutes and mixed throughout the house for an additional 10 minutes by the furnace fan. At that time, concentration measurements started and continued until the concentration dropped by $15 \%$. For another test the interior doors were opened and portable far:s, as well as the furnace fan, were used to obtain a uniform concentration of $\mathrm{SF}_{6}$ in the house. The furnace fan was then turned off and concentrations were measured to obtain the infiltration rate. The house was purged of $\mathrm{SF}_{6}$ after each test. 
For both tests, it is important to note the position of the basement door. If the door is open, then the infiltration is from a conditioned space, including the basement, to the outside. If the door is closed, then the infiltration is from a conditioned space, not including the basement, to the outside, and the basement acts as a buffer zone. It is important to check whether the basement has been fully purged before any test where the basement door is closed. The air in buffer zones should start with zero concentration so that the full air exchange with the basement is measured.

The air change rates calculated from the tracer-gas measurements are presented in Table 4 along with results from Modera et al. and Nelson et al. Air exchange rates with the fan on were 3 to 5 times those with the fan off. The air exchange rates with the fan off are below the ASHRAE Standard 62 (1990) minimum requirement of $0.35 \mathrm{ACH}$. The fan off results for houses $\mathrm{A}$ and $\mathrm{B}$ are biased to lower infiltration rates because the basement was not properly purged of $\mathrm{SF}_{6}$ before the test began. In the California study, 0.69 and $0.24 \mathrm{ACH}$ were found with fans on and off, respectively. One cause of the differences between the California study and the current results may again be the more compact shape of two story houses. For the tests when the basement door was closed, another difference is that the basements act as buffer zones since they are not well vented. In a house with a well vented crawlspace, air which is lost to the crawlspace is not as likely to return to the conditioned space. In a basement house, air lost to the basement is quite likely to return to the conditioned space. For the tests with the basement door closed, concentrations levels in the basement reached $15-30 \%$ of those in the conditioned zone.

TABLE 4. Whole-House Air Exchange Rates With and Without Distribution Fan in Operation

\begin{tabular}{|l|l|l|l|l|l|l|}
\hline & \multicolumn{2}{|l|}{ GEOMET House } & & \\
Conditions & $\mathbf{A}$ & $\mathbf{B}^{\mathbf{a}}$ & $\mathbf{C}^{\mathbf{b}}$ & $\mathbf{D}^{\mathbf{b}}$ & $\begin{array}{l}\text { Modera et al. } \\
(\mathbf{1 9 9 2 )}\end{array}$ & $\begin{array}{l}\text { Nelson et al. } \\
(\mathbf{1 9 9 3})^{\mathbf{b}}\end{array}$ \\
\hline fan on, doors open & $0.43^{\mathrm{b}}$ & 0.42 & 0.36 & 0.12 & 0.69 & 0.33 \\
\hline fan off, doors open & $0.15^{\mathrm{a}, \mathrm{c}}$ & $0.08^{\mathrm{c}}$ & 0.14 & - & 0.24 & 0.27 \\
\hline$($ fan on)/(fan off) & $\mathrm{n} / \mathrm{a}$ & $<5$ & 2.5 & $>6$ & 2.9 & 1.2 \\
\hline
\end{tabular}

abasement door closed

b basement door open

basement not purged fully after previous test, so this is an upper lim it

The ratio of the fan on and fan off infiltrations is much lower for the Nelson et al. houses. This is because the basement is part of the conditioned space in that study. The duct system is almost completely inside the conditioned envelope. When the duct system is inside the envelope, duct leakage will only cause infiltration if there are rooms with unbalanced ventilation. When interior doors are open, unbalanced ventilation can not occur. The $20 \%$ increase in infiltration which does occur for the Nelson et al. houses is due to duct leakage to outside. 


\subsection{Conduction losses}

Conduction losses were determined by dividing the average steady state temperature loss in the supply ducts by the steady state temperature rist from the return plenum to the supply plenum, i.e. the temperature rise over the heat exchanger. Average temperatures were found in the plenums by using multiple temperature probes. Average temperatures at the supply registers were found by measuring the temperature at several registers.

Table 5 presents the measured conduction losses in the supply ducts. House A presents an extreme case of $31 \%$ conduction losses on a very mild day. As an example of the complexity of houses, House A has a chaseway which reached a temperature of $34^{\circ} \mathrm{C}$ when the house temperature was 24 ${ }^{\circ} \mathrm{C}$. This occurs because the furnace flue is routed through the chaseway. The data presented here were taken in May and June of 1992 and do not represent extreme conditions. With temperature differences between the room and outside of only 2 to $9 \mathrm{~K}$, they are more representative of minimum losses. Conduction losses will be larger on cold winter days or hot summer days. The measured losses are comparable to the average of $23 \%$ which was found in the California study.

TABLE 5. Measured Conduction Losses in Supply Ducts

\begin{tabular}{|l|l|l|l|l|}
\hline & \multicolumn{3}{l}{ GEOMET House } \\
Characteristic & A & $\mathbf{B}^{\mathbf{a}}$ & $\mathbf{C}^{\mathbf{b}}$ & $\mathbf{D}^{\mathbf{b}}$ \\
\hline $\begin{array}{l}\text { Temperature Rise Across } \\
\text { Heat Exchanger (K) }\end{array}$ & 31.6 & 9.7 & 43.1 & 19.6 \\
\hline $\begin{array}{l}\text { Temperature Drop } \\
\text { Through Ducts (K) }\end{array}$ & 9.7 & 1.3 & 3.8 & 3.1 \\
\hline Room Temperature ( $\left.{ }^{\circ} \mathrm{C}\right)$ & 24 & 22 & 23 & 22 \\
\hline Outside Temperature $\left({ }^{\circ} \mathrm{C}\right)$ & 19 & 24 & 18 & 13 \\
\hline $\begin{array}{l}\text { Fractional Energy Loss } \\
\text { by Conduction }\end{array}$ & $31 \%$ & $14 \%$ & $9 \%$ & $16 \%$ \\
\hline $\begin{array}{l}\text { ateat pump } \\
\text { beat pump + electrical resistance heating }\end{array}$ & & & \\
\hline heat & & & \\
\hline
\end{tabular}

\subsection{Indoor-outdoor pressure differences}

Table 6 presents the indoor-outdoor pressure differences that were measured in zones with supply registers when all internal doors were closed and the fan was running. In general, these zones were pressurized. Some zones were found to be depressurized. For houses $\mathrm{A}$ and $\mathrm{C}$ the pressure differences are within $1 \mathrm{~Pa}$ of the average outdoor pressure on the house. However, house $\mathrm{D}$ has much larger indoor-outdoor pressure differences. One potentially confusing result is the existence of rooms with only supply registers that are depressurized when the HVAC fan is turned on. A room with only 
supply registers can be depressurized if it is adjarent to a room that is highly depressurized, e.g. a hallway with a return register and no supply registers.

TABLE 6. Indoor-Outdoor Pressure Differences for Various Conditions.

\begin{tabular}{|c|c|c|c|c|c|c|c|}
\hline \multirow{4}{*}{$\begin{array}{l}\text { interior } \\
\text { door } \\
\text { position } \\
\text { closed }\end{array}$} & \multirow{4}{*}{$\begin{array}{l}\text { HVAC } \\
\text { fan } \\
\text { condition }\end{array}$} & \multicolumn{2}{|l|}{ quantity } & \multirow{2}{*}{$\begin{array}{l}\text { A } \\
0.8\end{array}$} & \multirow{2}{*}{$\frac{B}{n / a}$} & \multirow{2}{*}{$\begin{array}{l}\mathrm{C} \\
1.4\end{array}$} & \multirow{2}{*}{$\begin{array}{c}\text { D } \\
5.3\end{array}$} \\
\hline & & pressure $(\mathrm{Pa})$ & mean & & & & \\
\hline & & in zones with & maximum & 3.7 & $\mathrm{n} / \mathrm{a}$ & 4.5 & 7.5 \\
\hline & & ters only & minimum & -0.7 & $\mathrm{n} / \mathrm{a}$ & -1.6 & 3.0 \\
\hline \multirow[t]{2}{*}{ open } & on & \multicolumn{2}{|c|}{ interior pressure $(\mathrm{Pa})$} & 0.1 & 1.6 & 0.4 & -0.9 \\
\hline & off & \multicolumn{2}{|c|}{ interior pressure $(\mathrm{Pa})$} & 0.0 & 0.5 & -0.5 & 0.0 \\
\hline
\end{tabular}

The conclusion which can be reached from the field measurements is that the potential for improving thermal distribution system efficiencies may be large. The total specific ELA of the ducts was approximately twice that found in attic and crawlspace duct systems in the sunbelt. However, only about $15 \%$ of the leakage area is leaks to outside, the remainder leaks mainly to the basement. Also, only one of the houses had any duct insulation, unlike sunbelt ducts which usually have R-4 insulation. However, it is not yet clear how important losses to a partly conditioned space are. Some fraction of the energy lost by the ducts to the basement is recovered. To estimate this fraction we performed computer simulations of a prototype house similar to those in this study.

\subsection{Simulation Results}

The field measurements presented in the previous section help to characterize basement houses. However, it is not possible to determine the potential for energy savings from the measurements. By performing computer simulations of a model house which is similar to those found in the field study, we can evaluate the potential for energy savings through duct system improvements.

The simulation system used is a combination of COMIS, DOE-2, and DUCTSIM. COMIS is an airflow network solver and is used to calculate all airflows. DOE-2 is a building load calculation program. DUCTSIM is a modified version of a program developed by one of the authors (Modera and Jansky, 1992). DUCTSIM calculates temperatures in the ducts by accounting for conduction and leakage losses. It also calculates the on-time ratio of the HVAC system while taking into account the thermal mass of the duct system. Finally, DUCTSIM combines the flow results from COMIS and the duct temperatures to provide air and heat flow information to DOE-2. 


\subsection{Definitions of quantities presented}

Results are presented here in the form of the figure of merit, $\eta_{\text {dist }}$ defined in Modera et al.(1992). $\eta_{\text {dist }}$, also called the thermal distribution system efficiency, is defined as:

$$
\eta_{\text {dist }}=\frac{E_{\text {no-dist }}}{E_{\text {dist }}}
$$

where $E_{n o-d i s t}$ and $E_{\text {dist }}$ are the energies required to condition the house with and without a distribution system, respectively. These energies are the input energies to the system, i.e. the electricity for the fan and air conditioner and gas for the furnace. The house without a distribution system is assumed to have local heaters or coolers with the same efficiency and characteristics as the central unit employed with the distribution system. The energy use may be written as:

$$
E=\frac{L}{\eta_{\text {nominal }} \cdot \eta_{\text {equipment }}}
$$

where:

$\mathrm{L}$ is the conditioning load on the house

$\eta_{\text {nominal }}$ is the nominal distribution system efficiency

$\eta_{\text {equipment }}$ is the equipment efficiency

$\eta_{\text {nominal }}$ may be derived from Equation 2. Rewriting Equation 1 using Equation 2 gives:

$$
\eta_{\text {dist }}=\eta_{\text {nominal }} \cdot\left[\frac{\eta_{\text {equip }_{\text {dist }}}}{\eta_{\text {equip }}}\right] \cdot\left[\frac{L_{\text {no-disus }}}{L_{\text {dist }}}\right]
$$

where the subscripts dist and no-dist refer to a house with and without a duct system, respectively. Results from simulations will be presented in the form of the three terms in Equation 3. The second and third terms in Equation 3 will often be greater than 1. The equipment efficiency ratio will be greater than 1 because the additional infiltration caused by duct leakage will increase the on time of the HVAC system and increase its efficiency. The load ratio will often be greater than 1 because $\mathrm{L}_{\text {dist }}$ is the energy intentionally delivered to the conditioned space. The unintentional delivery of energy to the conditioned space, for example by duct leaks heating the basement, reduces $\mathrm{L}_{\text {dist }}$.

\subsection{House and Parameter Description}

Results are presented here from ten annual simulations of a prototype house for one year. The house is described in Table 7. The simulations performed are shown in Table 8. Simulations were performed for three geographical locations, three duct systems, and two interior door positions. The 
three locations were Atlanta, GA, Minneapolis, MN, and Washington, D.C. The three ducts systems were called normal, improved, and perfect. The "normal" system, consisted of uninsulated sheet metal ducts with $400 \mathrm{~cm}^{2}$ of leakage area. In the improved system, the ducts in the basement are insulated to an R-value of $0.88^{\circ} \mathrm{C} \cdot \mathrm{m}^{2} / \mathrm{W}\left(\mathrm{R}-5^{\circ} \mathrm{F} \cdot \mathrm{ft} 2 \cdot \mathrm{h} / \mathrm{BTU}\right)$ and have an ELA of $80 \mathrm{~cm}^{2}$. Ducts in walls were not insulated because of space limitations in wall stud cavities. The leakage area of the improved system corresponds to the original system with $80 \%$ of its leaks sealed. In the "perfect" duct system, all of the ducts are insulated to an R-value of $17.6^{\circ} \mathrm{C} \cdot \mathrm{m}^{2} / \mathrm{W}\left(\mathrm{R}-100^{\circ} \mathrm{F} \cdot \mathrm{ft} 2 \cdot \mathrm{h} / \mathrm{BTU}\right)$ and have an ELA of $0 \mathrm{~cm}^{2}$.

TABLE 7. Craracteristics of the model house

\begin{tabular}{|c|c|c|}
\hline \multicolumn{2}{|l|}{ Construction } & Two-story w/Attic \\
\hline \multicolumn{2}{|l|}{ Foundation } & basement \\
\hline \multicolumn{2}{|l|}{ Floor Area } & $104 \mathrm{~m}^{2}$ per floor \\
\hline \multicolumn{2}{|c|}{ Basement, Interior Wall, and Floor Insulation } & none \\
\hline \multicolumn{2}{|c|}{ Ceiling Insulation } & R-19 \\
\hline \multicolumn{2}{|l|}{ Exterior Wall Insulation } & R-11 \\
\hline \multicolumn{2}{|l|}{ Windows } & double-paned \\
\hline \multirow{4}{*}{$\begin{array}{l}\text { Envelope Leakage } \\
\text { Area }\end{array}$} & total & $829 \mathrm{~cm}^{2}\left(4 \mathrm{~cm}^{2} / \mathrm{m}^{2}\right.$ of floor area) \\
\hline & to attic & $207 \mathrm{~cm}^{2}$ \\
\hline & to basement & $207 \mathrm{~cm}^{2}$ \\
\hline & to outside & $414 \mathrm{~cm}^{2}$ \\
\hline $\begin{array}{l}\text { Basement Leakage } \\
\text { Area }\end{array}$ & to outside & $75 \mathrm{~cm}^{2}$ \\
\hline \multirow[t]{3}{*}{ Return Leakage Area } & total & $200 \mathrm{~cm}^{2}\left(0.96 \mathrm{~cm}^{2} / \mathrm{m}^{2}\right.$ of floor area $)$ \\
\hline & to basement & $167 \mathrm{~cm}^{2}$ \\
\hline & to envelope & $33 \mathrm{~cm}^{2}$ \\
\hline \multirow[t]{4}{*}{ Supply Leakage Area } & total & $200 \mathrm{~cm}^{2}\left(0.96 \mathrm{~cm}^{2} / \mathrm{m}^{2}\right.$ of floor area $)$ \\
\hline & to basement & $132 \mathrm{~cm}^{2}$ \\
\hline & to envelope & $27 \mathrm{~cm}^{2}$ \\
\hline & to outside & $41 \mathrm{~cm}^{2}$ \\
\hline \multirow[t]{3}{*}{ Duct U-value } & in basement & $4.5 \mathrm{~W} / \mathrm{m}^{20} \mathrm{C}\left(0.8 \mathrm{Btu} /\left(\mathrm{hr} \mathrm{ft}{ }^{2}{ }^{\circ} \mathrm{F}\right)\right.$ \\
\hline & in $\mathrm{R}-11$ exterior walls & $1.0 \mathrm{~W} / \mathrm{m}^{2 \circ} \mathrm{C}$ \\
\hline & in Interior Walls & $2.7 \mathrm{~W} / \mathrm{m}^{20} \mathrm{C}$ \\
\hline \multicolumn{2}{|l|}{ Door Undercut } & $1.0 \mathrm{~cm}$ \\
\hline \multicolumn{2}{|l|}{ Operation } & $\begin{array}{l}\text { Heating Setpoint } 20^{\circ} \mathrm{C}\left(68^{\circ} \mathrm{F}\right) \text {, no night set back } \\
\text { Cooling Setpoint } 26^{\circ} \mathrm{C}\left(78^{\circ} \mathrm{F}\right) \\
\text { Window Openings based on Outdoor Enthalpy }\end{array}$ \\
\hline
\end{tabular}

The prototype house and duct system were chosen to be typical of the results from the field measurements and literature. The envelope leakage area chosen is representative of the leakage area found in the field tests above. The duct leakage area chosen is also representative of the field test results. The pressures in the duct system are typically $-60,-20,20$, and $10 \mathrm{~Pa}$ in the return plenum, return duct, supply plenum, and supply ducts, respectively. This is within the range of the field measurements. 
TABLE 8. Description of runs

\begin{tabular}{|c|c|c|c|}
\hline run & location & $\begin{array}{l}\text { door } \\
\text { position }\end{array}$ & duct system \\
\hline 1 & Atlanta, GA & \multirow[t]{3}{*}{ closed } & \multirow[t]{6}{*}{ normal $^{b}$} \\
\hline 2 & Minneapolis, MN & & \\
\hline 3 & Washington, D.C. & & \\
\hline 4 & Atlanta, GA & \multirow[t]{3}{*}{ open } & \\
\hline 5 & Minneapolis, MN & & \\
\hline 6 & Washington, D.C. & & \\
\hline 7 & Atlanta, GA & \multirow[t]{3}{*}{ open } & \multirow[t]{3}{*}{ improved $^{c}$} \\
\hline 8 & Minneapolis, MN & & \\
\hline 9 & Washington, D.C. & & \\
\hline 20 & Washington, D.C. & open & perfect ${ }^{d}$ \\
\hline
\end{tabular}

${ }^{a}$ for interior doors, door to basement is always closed

buninsulated sheet metal ducts $w$ ith $400 \mathrm{~cm}^{2}$ ELA

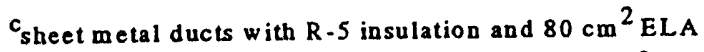

sheet metal ducts $w$ ith $R-100$ insulation and $0 \mathrm{~cm}^{2}$ ELA

Most of the ELA's between the basement, conditioned space, attic, and outside were set assuming $2 \mathrm{~cm}^{2}$ of ELA per $\mathrm{m}^{2}$ of floor or wall area between the zones. The exceptions are: the ELA between the attic and outside, in which a certain venting area, $3000 \mathrm{~cm}^{2}$, was added; and the leakage from the basement to outside for which an ELA of $3 \mathrm{~cm}^{2}$ per $\mathrm{m}^{2}$ of area is assumed.

For the closed door results listed below, the size of the opening under the door is assumed to be $1 \mathrm{~cm}$, which was typical of the houses studied above. This is also typical of the houses investigated the study of 31 California houses. The door ELA, when open, was assumed to be $9900 \mathrm{~cm}^{2}$. The flow exponent for both open and closed doors was assumed to be 0.5 .

\subsection{Time Averaged Results for Infiltration from Annual Simulations}

Time averaged results from annual simulations for various mass flows for the different duct systems and door positions are given in Table 9. For each city, results are presented for two cases: 1) normal distribution system with doors open; and 2) an improved distribution system with doors open. For each of these cases, results are shown for: a) no distribution system, b) distribution system with fan on/off results weighted by ontime, $c$ ) distribution system with fan on, and d) distribution system with fan off. The total house infiltration is the sum of all flows going into the house from the unconditioned spaces and outside, including the basement. This includes the fraction of air which enters the duct system and then enters the house as well as air which enters the conditioned space directly. The envelope infiltration/exfiltration is the sum of all of the flows going in/out of the house through the walls, ceilings, and floors, but not through the ducts. Because the duct system's leakage area is primarily in the basement, most of the duct leakage flows are to and from the basement. Because 
the return duct system does not leak to the outside and the supply duct system is at a positive pressure with the fan on, all of the duct infiltration for the fan on case is from the basement.

\section{Thermosyphon effect}

Modera and Jansky (1992) showed that thermosyphon flow may be more important than duct leakage for certain duct configurations when the distribution system fan is off. The placement of duct branches in both interior and exterior walls is a configuration for which the thermosyphon effect could be important. This effect has not been modelled in the simulation results presented here and is a topic for future research.

\section{Results}

The data in Table 9 may be analyzed for the effects of weather while that in Table 10 shows the effect of duct sealing. The variation in performance due to weather can be seen from the simulations for different geographic locations. Comparing the infiltration results for the three cities, it is seen that the weather can cause large changes in infiltration. The average total infiltration with a normal, no leaks sealed, distribution system in Minneapolis is 54\% greater than that for Atlanta, and 33\% greater than that for Washington. An obvious hypothesis would be that the higher infiltration for Minneapolis is due to a longer on time for the fan. However, Minneapolis has $44 \%$ and $31 \%$ higher infiltration rates than Atlanta and Washington, respectively, for the no distribution system case. Therefore, the increase is due to a larger stack effect in harsher winters or an increased average wind speed. The average wind speeds are $3.8,4.1$, and $4.7 \mathrm{~m} / \mathrm{s}$ for Atlanta, Washington, and Minneapolis, respectively.

Simulations were performed for closed interior doors but the results are not presented here because of the small effect on $\eta_{\text {dist }}$. The overall effect of opening and closing doors on infiltration is also small for the prototype house. The increase in the average annual infiltration rate due to closing doors is 7 to $9 \mathrm{~kg} / \mathrm{hr}$, or less than $3 \%$ of the total house infiltration. For the case with no distribution system, the infiltration is lowered $1-2 \mathrm{~kg} / \mathrm{hr}$ when doors are closed. Closed doors do have a large effect when the fan is on; infiltration is increased by $6-10 \%$ over the open door case. For the fan off case with a distribution system present, closing the doors increases the infiltration 1-2\%.

The results in Table 10 show that the house infiltration generally increases by a factor of 2.8 to 4 when the fan is turned on ard interior doors are open. This is within the range found in the field measurements. 
TABLE 9. House Air Exchange and Duct Infiltration/Exfiltration $(\mathrm{kg} / \mathrm{hr})$

\begin{tabular}{|c|c|c|c|c|c|c|c|}
\hline \multirow{2}{*}{ Case } & \multirow{2}{*}{ Quantity } & \multicolumn{6}{|c|}{$\begin{array}{l}\text { Conditions } \\
\text { standard leakage }\end{array}$} \\
\hline & & Wash. & Atl. & Minn. & Wash. & Atl. & Minn. \\
\hline \multirow{5}{*}{$\begin{array}{l}\text { No Distribution Sys- } \\
\text { tem }\end{array}$} & \multirow{2}{*}{$\begin{array}{l}\text { Total House Infiltration in } \\
\mathrm{kg} / \mathrm{hr} \text { and }(\mathrm{ACH})\end{array}$} & 164 & 149 & 215 & \multirow{5}{*}{\multicolumn{3}{|c|}{ same as to the left }} \\
\hline & & $(0.26)$ & $(0.24)$ & $(0.35)$ & & & \\
\hline & Infiltration from Attic & 16 & 9 & 12 & & & \\
\hline & Infiltration from Basement & 21 & 18 & 35 & & & \\
\hline & Infiltration from Outside & 126 & 120 & 166 & & & \\
\hline \multirow{9}{*}{$\begin{array}{l}\text { Actual infiltration } \\
\text { (distribution system is } \\
\text { presents and fan on/off } \\
\text { results are weighted } \\
\text { by ontime) }\end{array}$} & \multirow{2}{*}{$\begin{array}{l}\text { Total House Infiltration in } \\
\mathrm{kg} / \mathrm{hr} \text { and }(\mathrm{ACH})\end{array}$} & 256 & 227 & 335 & 182 & 164 & 235 \\
\hline & & $(0.41)$ & $(0.36)$ & $(0.54)$ & $(0.29)$ & $(0.26)$ & $(0.38)$ \\
\hline & Duct Infil tration $^{a}$ & 112 & 94 & 154 & 27 & 23 & 39 \\
\hline & Duct Exfiltration $^{\mathrm{a}}$ & 32 & 26 & 44 & 6 & 5 & 8 \\
\hline & Envelope Infiltration ${ }^{b}$ & 144 & 132 & 180 & 154 & 141 & 195 \\
\hline & Envelope Exfiltration ${ }^{\mathrm{d}}$ & 223 & 201 & 291 & 175 & 158 & 226 \\
\hline & Infiltration from Attic ${ }^{d}$ & 17 & 10 & 13 & 16 & 9 & 13 \\
\hline & Infiltration from Basement ${ }^{d}$ & 2 & 3 & 2 & 11 & 10 & 17 \\
\hline & Infiltration from Outside ${ }^{d}$ & 124 & 118 & 163 & 125 & 120 & 165 \\
\hline \multirow{9}{*}{$\begin{array}{l}\text { Distribution System } \\
\text { With Fan On }\end{array}$} & \multirow{2}{*}{$\begin{array}{l}\text { Total House Infiltration in } \\
\mathrm{kg} / \mathrm{hr} \text { and }(\mathrm{ACH})\end{array}$} & 769 & 733 & 792 & 319 & 298 & 352 \\
\hline & & $(1.24)$ & $(1.18)$ & $(1.27)$ & $(0.51)$ & $(0.48)$ & $(0.57)$ \\
\hline & Duct Infil tration ${ }^{c}$ & 623 & 600 & 609 & 172 & 165 & 168 \\
\hline & Duct Exfiltration ${ }^{a}$ & 282 & 271 & 269 & 66 & 63 & $\overline{63}$ \\
\hline & Envelope Infiltration ${ }^{\mathrm{d}}$ & 145 & 132 & 182 & 146 & 133 & 183 \\
\hline & Envelope Exfiltration ${ }^{d}$ & 486 & 462 & 523 & 251 & 234 & 288 \\
\hline & Infiltration from Attic ${ }^{d}$ & 16 & 9 & 13 & 17 & 10 & 13 \\
\hline & Infiltration from Basement ${ }^{d}$ & 0 & 0 & 0 & 0 & 0 & 1 \\
\hline & Infiltration from Outside ${ }^{\mathrm{d}}$ & 128 & 122 & 169 & 128 & 122 & 168 \\
\hline \multirow{9}{*}{$\begin{array}{l}\text { Distribution System } \\
\text { With Fan Off }\end{array}$} & \multirow{2}{*}{$\begin{array}{l}\text { Total House Infiltration in } \\
\mathrm{kg} / \mathrm{hr} \text { and }(\mathrm{ACH})\end{array}$} & 201 & 182 & 256 & 170 & 154 & 221 \\
\hline & & $(0.32)$ & $(0.29)$ & $(0.41)$ & $(0.27)$ & $(0.25)$ & $(0.36)$ \\
\hline & Duct Infiltration $^{\mathrm{a}}$ & 56 & 49 & 76 & 14 & 12 & 21 \\
\hline & Duct Exfiltration $^{\mathrm{a}}$ & 5 & 4 & 5 & 1 & 0 & 1 \\
\hline & Envelope Infiltration & 144 & 132 & 179 & 155 & 141 & 199 \\
\hline & Envelope Exfiltration $^{\mathrm{d}}$ & 194 & 177 & 250 & 168 & 153 & 220 \\
\hline & Infiltration from Attic ${ }^{d}$ & 17 & 10 & 13 & 16 & 9 & 13 \\
\hline & Infiltration from Basement $^{d}$ & 2 & 3 & 4 & 12 & 12 & 21 \\
\hline & Infiltration from Outside & 124 & 118 & 162 & 125 & 119 & 165 \\
\hline
\end{tabular}

aprimarily with basement, some with outside

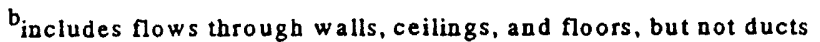

$c_{\text {from basement only, since return has no leakage to outside }}$ 
TABLE 10. Effects of duct sealing on infiltration/exfiltration $(\mathrm{kg} / \mathrm{hr})$ for a house with open doors Washington

\begin{tabular}{|c|c|c|c|c|}
\hline Case & Quantity & Duct Cor & Improved & Perfect $^{b}$ \\
\hline \multirow{9}{*}{$\begin{array}{l}\text { Actual infiltration } \\
\text { (distribution system } \\
\text { is presents and fan } \\
\text { on/off results are } \\
\text { weighted by ontime) }\end{array}$} & \multirow{2}{*}{$\begin{array}{l}\text { Total House Infiltration in } \\
\mathrm{kg} / \mathrm{hr} \text { and }(\mathrm{ACH})\end{array}$} & 256 & 182 & 164 \\
\hline & & $(0.41)$ & $(0.29)$ & $(0.26)$ \\
\hline & Duct Infiltration ${ }^{c}$ & 112 & 27 & 0 \\
\hline & Duct Exfiltration $^{\mathrm{a}}$ & 32 & 6 & 0 \\
\hline & Envelope Infiltration ${ }^{d}$ & 144 & 154 & 164 \\
\hline & Envelope Exfiltration $^{\mathrm{d}}$ & 223 & 175 & 164 \\
\hline & Infiltration from Attic ${ }^{d}$ & 17 & 16 & 16 \\
\hline & Infiltration from Basement ${ }^{d}$ & 2 & 11 & 21 \\
\hline & Infiltration from Outside ${ }^{d}$ & 124 & 125 & 126 \\
\hline \multirow{9}{*}{$\begin{array}{l}\text { Distribution System } \\
\text { With Fan On }\end{array}$} & \multirow{2}{*}{$\begin{array}{l}\text { Total House Infil tration in } \\
\mathrm{kg} / \mathrm{hr} \text { and }(\mathrm{ACH})\end{array}$} & 769 & 319 & 164 \\
\hline & & $(1.24)$ & $(0.51)$ & $(0.26)$ \\
\hline & Duct Infil tration ${ }^{e}$ & 623 & 172 & $\overline{0}$ \\
\hline & Duct Exfiltration ${ }^{a}$ & 282 & 66 & 0 \\
\hline & Envelope Infiltration $^{\mathrm{d}}$ & 145 & 146 & 164 \\
\hline & Envelope Exfiltration ${ }^{d}$ & 486 & 251 & 164 \\
\hline & Infiltration from Attic ${ }^{d}$ & 16 & 17 & 16 \\
\hline & Infiltration from Basement ${ }^{d}$ & 0 & 0 & 21 \\
\hline & Infiltration from Outside ${ }^{\mathrm{d}}$ & 128 & 128 & 126 \\
\hline \multirow{9}{*}{$\begin{array}{l}\text { Distribution System } \\
\text { With Fan Off }\end{array}$} & \multirow{2}{*}{$\begin{array}{l}\text { Total House Infil tration in } \\
\mathbf{k g} / \mathrm{hr} \text { and }(\mathrm{ACH})\end{array}$} & 201 & 170 & 164 \\
\hline & & $(0.32)$ & $(0.27)$ & $(0.26)$ \\
\hline & Duct Infil tration $^{\mathbf{a}}$ & 56 & 14 & 0 \\
\hline & Duct Exfiltration $^{\mathrm{a}}$ & 5 & 1 & 0 \\
\hline & Envelope Infiltration ${ }^{d}$ & 144 & 155 & 164 \\
\hline & Envelope Exfiltration $^{\mathrm{d}}$ & 194 & 168 & 164 \\
\hline & Infiltration from Attic ${ }^{d}$ & 17 & 16 & 16 \\
\hline & Infiltration from Basement ${ }^{d}$ & 2 & 12 & 21 \\
\hline & Infiltration from Outside ${ }^{d}$ & 124 & 125 & 126 \\
\hline
\end{tabular}

${ }^{a} \mathrm{R}-5$ insulation on ducts in basement and $80 \%$ of duct leaks sealed.

$b_{R}-100$ insulation on all ducts and $100 \%$ of duct leaks sealed

c primarily with basement, some with outside

does not include flows through ducts

from basement only, since return has no leakage to outside 
In Table 10 infiltration results are presented for the house in Washington D.C. with the three different duct systems with open doors. As would be expected, infiltration does not change with fan operation for the perfect ducts and is the same as for the no-duct case in Table 9. The effects of duct sealing on envelope infiltration are also dramatic for the improved duct system. The infiltration decreases by $32 \%, 69 \%$, and $21 \%$ for the fan on/off, fan on, and fan off cases, respectively, compared to the normal duct system. These percentages correspond to $86,452,44 \mathrm{~kg} / \mathrm{hr}$ for the same cases, respectively. It was expected that the infiltration for the fan on case would decrease dramatically when the ducts were sealed. However, since the average on-time for the system for the year is near $10 \%$, the reduction in infiltration for the fan off case is of equal importance to annual energy consumption even though it is an order of magnitude smaller. Table 9 presented results for the improved duct systems in all three cities. It shows that infiltration for the fan on/off case decreases by a larger percentage as winters become harsher; i.e. Minnesota shows a larger gain than Washington and Washington shows a larger gain than Atlanta. This is a consequence of the longer on-times in harsher weather conditions.

Table 11 contains results for $\eta_{\text {dist }}$, the distribution system efficiency, and related quantities for the same cases as in Table 9. Table 12 presents the same quantities for the prototype house located in Washington, D.C. with normal, improved, and perfect ducts. Again, the effects of weather, door position, and duct improvements are noted. It is also of interest to compare heating and cooling results.

The effects of door position and weather are small. $\eta_{\text {dist }}$ varies by 2 to 3 percentage points between the cities. There is no trend for $\eta_{\text {dist }}$ with severity of weather. Although the results are not shown here, door position also has a small effect on $\eta_{\text {dist }}$. When the doors are closed, $\eta_{\text {dist }}$ is 1-2 percentage points lower in Washington and Minnesota and 1 percentage point higher in Atlanta.

The most notable difference between heating and cooling is that $\eta_{\text {dist }}$ is $8 \%$ lower for cooling normal ducts, $13 \%$ lower for improved ducts, $20 \%$ lower for perfect ducts. This seems counter-intuitive because the temperature difference between the basement and duct system is smaller for cooling. For Washington D.C. the basement temperature typically ranges from 12 to $20^{\circ} \mathrm{C}$ in the winter and from 24 to $26^{\circ} \mathrm{C}$ in the summer. Typical duct temperatures for heating and cooling are 49 and $10^{\circ} \mathrm{C}$, respectively. There are temperature differences between the ducts and the basement of 33 $\mathrm{K}$ and $14 \mathrm{~K}$ for heating and cooling, respectively. There is a much larger temperature difference for heating. There are two effects that counter this static effect. In heating the energy used to run the fan increases the heat delivered. The fan energy must be overcome in cooling. The no-distribution system case does not use a fan and would inherently use less energy for cooling. The second effect arises from the thermal mass stored in the ducts. For heating, the fan continues to run after the burner turns off in order to extract the energy which went into heating the heat exchanger. Coincidentally, and more importantly, this fan c zrrun also extracts energy which went into heating the duct system and delivers 
it to the conditioned space. For cooling, there is condensation on the cooling coil and fan overrun is undesirable because it will rehumidify the air. The energy which goes into cooling the coil and the ducts is lost. The perfect duct case shows that in the cooling case the fan energy accounts for a 20 percentage point change in $\eta_{\text {dist }}$ for the locations simulated. All of the energy which goes into cooling the ducts is recovered in this case. The energy lost in the ducts accounts for another 2 to 3 percentage point change in $\eta_{\text {dist }}$ between the normal and perfect duct cases.

The basement and duct temperatures explain the change in load ratios between heating and cooling. For heating, the large temperature losses for the normal ducts increase the basement temperature and this results in a load decrease of 40 to $50 \%$ relative to the no-distribution system case. A smaller value of $\mathrm{L}_{\mathrm{no} \text {-duct }} / \mathrm{L}_{\text {duct }}$ is found for the cooling case because the basement temperature is not changed as much as for heating. This causes a smaller decrease in the load of 20 to $25 \%$. This change in load decreases as the duct system insulation and sealing are improved. From Table 12 it can be seen that for heating the house in Washington, D.C., the load ratio changes from 1.50 to 1.00 as ducts are made "perfect". For cooling the load ratio changes from 1.25 to 1.00.

The ratio $L_{\text {no-duct }} / L_{\text {duct }}$ is a measure of how much of the energy which is lost by the duct system is still received by the conditioned space. The recovered energy is $32 \%$ of the load with the distribution system in place for the unimproved duct system. It is $17 \%$ for the improved duct system. Because some of the energy lost by the duct system is recovered, the savings brought about by sealing and insulating the ducts are smaller than those suggested by changes in the nominal efficiency

The equipment efficiency ratio is another reason that $\eta_{\text {dist }}$ changes more slowly than $\eta_{\text {nominal }}$. $\eta_{\text {equip }}$ decreases as the equipment on-time ratio decreases. Therefore, as the duct system is improved and $\eta_{\text {nominal }}$ increases, the equipment efficiency ratio decreases and takes back some of the gains in $\eta_{\text {nominal }}$

The results in Table 12 show that the improved duct system has efficiencies which are 8 to 12 percentage points higher than for the normal duct system. Table 12 presents quantities pertaining to $\eta_{\text {dist }}$ for a house in Washington D.C. with normal, improved, and perfect ducts. The load and equipment efficiency ratios are both 1 for the "perfect" duct system.

Table 13 shows the combined heating and cooling results for $\eta_{\text {dist }}$ in the three cities for the three duct systems. The important number is that $\eta_{\text {dist }}$ increases by eight to ten percentage points when "normal" ducts are changed "improved" ducts. In Washington, D.C., the "perfect" ducts produced a further 6 percentage point gain in $\eta_{\text {dist }}$ to ninety nine percent. 
TABLE 11. Annual Simulation Results Showing the Effects of Weather and Duct Condition.

\begin{tabular}{|c|c|c|c|c|c|}
\hline Parameter & Location & \multicolumn{2}{|l|}{ Heating } & \multicolumn{2}{|l|}{ Cooling } \\
\hline \multirow{3}{*}{$\overline{\eta_{\text {dist }}}$} & Washington & 0.86 & 0.95 & 0.78 & 0.80 \\
\hline & Atlanta & 0.83 & 0.95 & 0.77 & 0.80 \\
\hline & Minneapolis & 0.83 & 0.94 & 0.76 & 0.80 \\
\hline \multirow{3}{*}{$\overline{\eta_{\text {nominal }}} \mathrm{b}$} & Washington & 0.54 & 0.81 & 0.58 & 0.70 \\
\hline & Atlanta & 0.54 & 0.81 & 0.56 & 0.69 \\
\hline & Minneapolis & 0.54 & 0.80 & 0.59 & 0.70 \\
\hline \multirow{3}{*}{$\eta_{\text {nominal }}$} & Washington & 0.61 & 0.83 & 0.67 & 0.81 \\
\hline & Atlanta & 0.61 & 0.83 & 0.67 & 0.81 \\
\hline & Minneapolis & 0.60 & 0.83 & 0.75 & 0.81 \\
\hline \multirow{3}{*}{$\eta_{\text {nominal }} l_{\min }$} & Washington & 0.49 & 0.79 & 0.53 & 0.67 \\
\hline & Atlanta & 0.49 & 0.79 & 0.52 & 0.67 \\
\hline & Minneapolis & 0.45 & 0.77 & 0.54 & 0.67 \\
\hline \multirow{3}{*}{$\overline{\eta_{\text {thermal }}}$} & Washington & 0.54 & 0.80 & 0.72 & 0.87 \\
\hline & Atlanta & 0.54 & 0.80 & 0.72 & 0.86 \\
\hline & Minneapolis & 0.54 & 0.79 & 0.73 & 0.87 \\
\hline \multirow{3}{*}{$\overline{\overline{L_{n o-d i s t}}} \overline{\overline{L_{\text {dist }}}}$} & Washington & 1.50 & 1.16 & 1.25 & 1.12 \\
\hline & Atlanta & 1.43 & 1.14 & 1.25 & 1.12 \\
\hline & Minneapolis & 1.48 & 1.16 & 1.19 & 1.10 \\
\hline \multirow{3}{*}{$\overline{\overline{\eta_{\text {equip }_{\text {dist }}}} c}$} & Washington & 1.06 & 1.02 & 1.08 & 1.02 \\
\hline & Atlanta & 1.07 & 1.02 & 1.09 & 1.02 \\
\hline & Minneapolis & 1.04 & 1.01 & 1.07 & 1.02 \\
\hline
\end{tabular}

\subsection{Hourly Simulation Results}

While the annual results listed above provide the numbers for estimates of potential savings from retrofits to duct systems, hourly results will provide insight into the physical processes occurring.

Figures 1-4 present hourly temperature and efficiency data for the prototype house in Washington, D.C. with open interior foors and the "normally" leaky uninsulated duct system. This data is presented to indicate the typical temperatures and efficiencies. There are hours for which the load is at or near zero for the house and this can cause extreme values in these quantities. Since these times represent small energy usage, the periods of heavier loads are of more interest. Therefore the spikes at the edges of the load periods will not be discussed.

In Figures 1 and 3 the zone temperatures are given for August 1-7 and January 1-7, respectively. The most striking feature of the summer temperatures is the extreme peaks in $\mathrm{T}_{\text {attic }}$. For the winter 
TABLE 12. Annual Simulation Results Showing the Effects of Duct Improvements on a House in Washington DC with Open Interior Doors.

\begin{tabular}{|c|c|c|c|c|c|c|}
\hline Parameter & $\begin{array}{l}\text { Heating } \\
\text { Typical }\end{array}$ & Improved & Perfect & $\begin{array}{l}\text { Cooling } \\
\text { Typical }\end{array}$ & Improved & Perfect \\
\hline$\overline{\eta_{\text {dist }}}$ & 0.86 & 0.95 & 1.00 & 0.78 & 0.80 & 0.81 \\
\hline$\overline{{\overline{\eta_{\text {nominal }}}}} \mathrm{c}$ & 0.54 & 0.81 & 1.00 & 0.58 & 0.70 & 0.80 \\
\hline$\overline{\eta_{\text {thermal }}} \mathrm{d}$ & 0.54 & 0.80 & 1.00 & 0.72 & 0.87 & 1.00 \\
\hline$\overline{\frac{L_{\text {no-dist }}}{\overline{L_{\text {dist }}}}}$ & 1.50 & 1.16 & 1.00 & 1.25 & 1.12 & 1.00 \\
\hline$\frac{\overline{\eta_{\text {equip }}}}{\eta_{\text {equit }}}$ e & 1.06 & 1.02 & 1.00 & 1.08 & 1.02 & 1.00 \\
\hline
\end{tabular}

${ }^{a} R-5$ insulation on ducts in basement and $80 \%$ of duct leaks sealed.

${ }^{b} R-40$ insulation on all ducts and $100 \%$ of duct leaks sealed

caverage calculated with weighting by En equip

daverage calculated with weighting by E E lequip

everage calculated with weighting by $E \eta_{\text {nominal }}$

TABLE 13. Annual averages of $\eta_{\text {dist }}$ for both beating and cooling combined.

\begin{tabular}{|l|l|l|l|}
\hline & \multicolumn{2}{|l|}{$\begin{array}{l}\text { Annual average of } \eta_{\text {dlst }} \text { for heating and } \\
\text { coollng }\end{array}$} \\
City & $\begin{array}{l}\text { norm al } \\
\text { ducts }\end{array}$ & $\begin{array}{l}\text { Im proved } \\
\text { ducts }\end{array}$ & $\begin{array}{l}\text { perfect } \\
\text { ducts }\end{array}$ \\
\hline Atlanta, GA & 0.82 & 0.92 & n/a \\
\hline Minneapolis, MN & 0.83 & 0.94 & n/a \\
\hline Washington, D.C. & 0.85 & 0.93 & 0.99 \\
\hline
\end{tabular}

temperatures, the difference in $T_{\text {basement }}$ between the cases with and without a distribution system is large. During times of low $\mathrm{T}_{\text {out }}$, the furnace is on for longer and the basement gets warm.

Figures 2 and 4 present time series of $\eta_{\text {dist }}, \eta_{\text {nominal }}, \eta_{\text {equip,dist }} / \eta_{\text {equip,no dist }}$ and $L_{\text {no-dist }} / L_{\text {dist }}$ for August 1-7 and January 1-7, respectively. The main point to notice in these figures is that the load ratio is significantly greater than one. This occurs because the load is defined as the energy delivered at the registers. However, in the distribution system case energy is also being delivered through leakage, conduction, and heating/cooling the basement. This unintentional delivery of energy is also why $\eta_{\text {dist }}$ is much greater than $\eta_{\text {nominal }} \cdot \eta_{\text {nominal }}$ reflects how much energy is delivered directly via the supply registers, while $\eta_{\text {dist }}$ reflects how much energy is delivered to the house by all paths. 


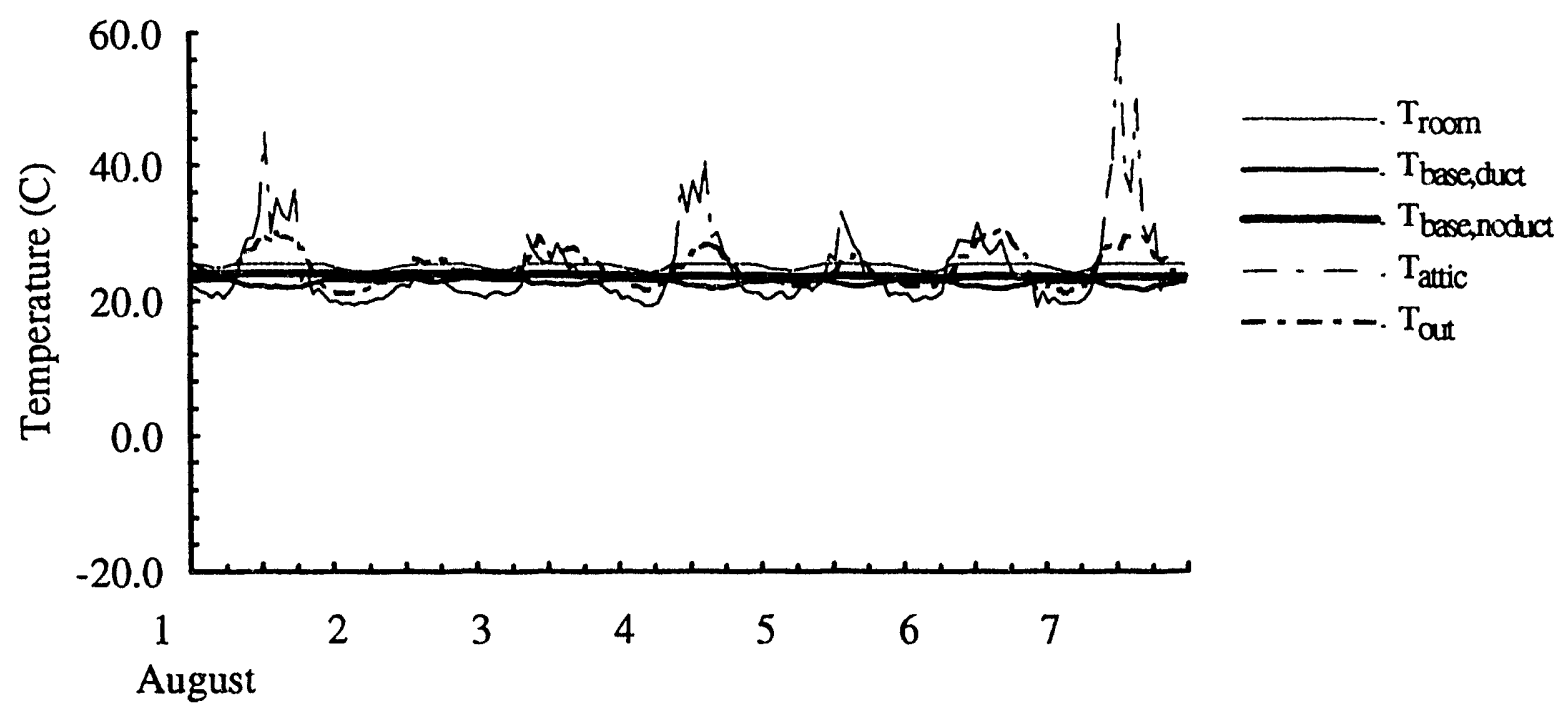

date

FIGURE 1. Zone temperatures for Washington with typical ducts for August 1-7.

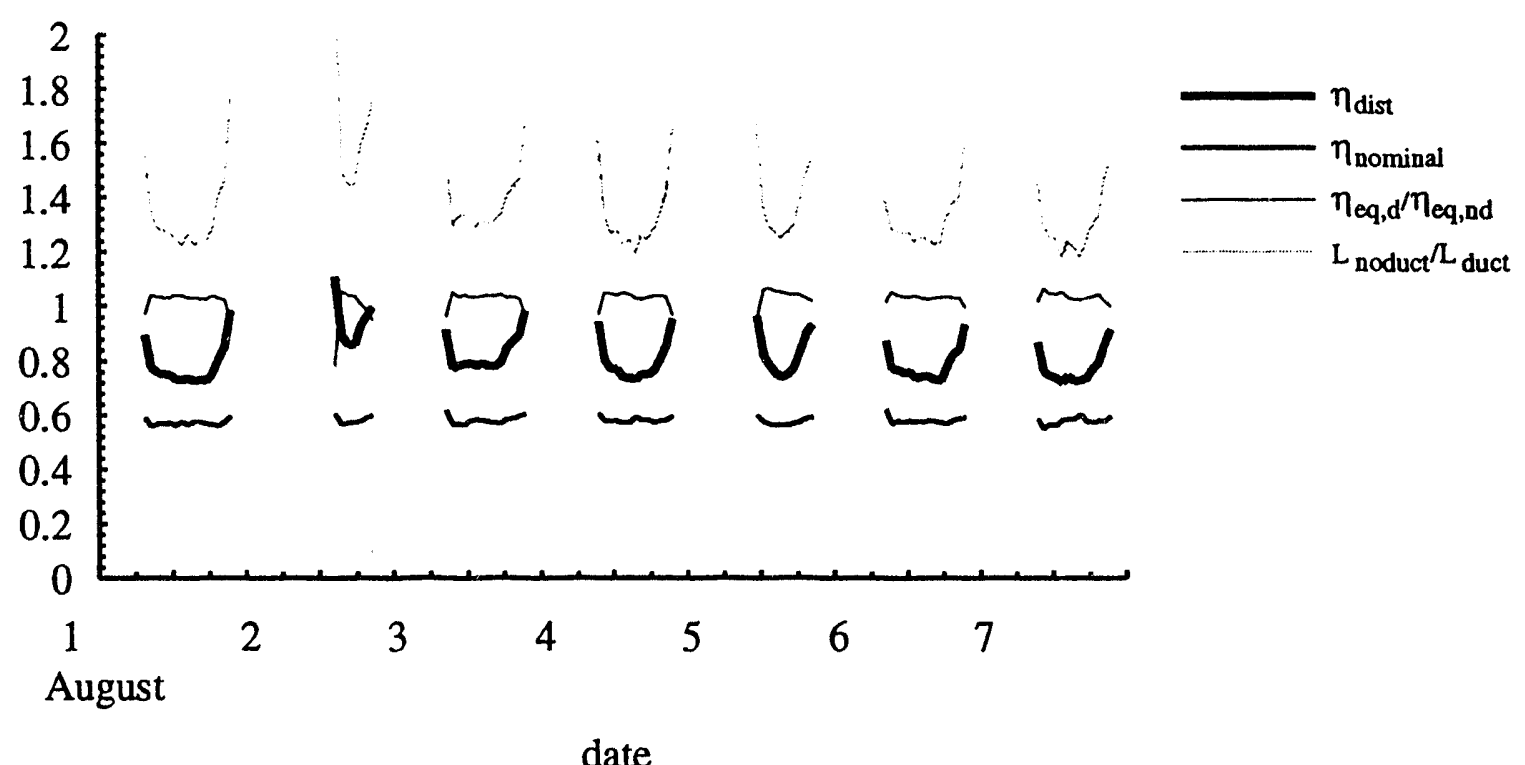

FIGURE 2. Quantities for $\eta_{\text {dist }}$ for Washington with normal ducts for August 1.7. 


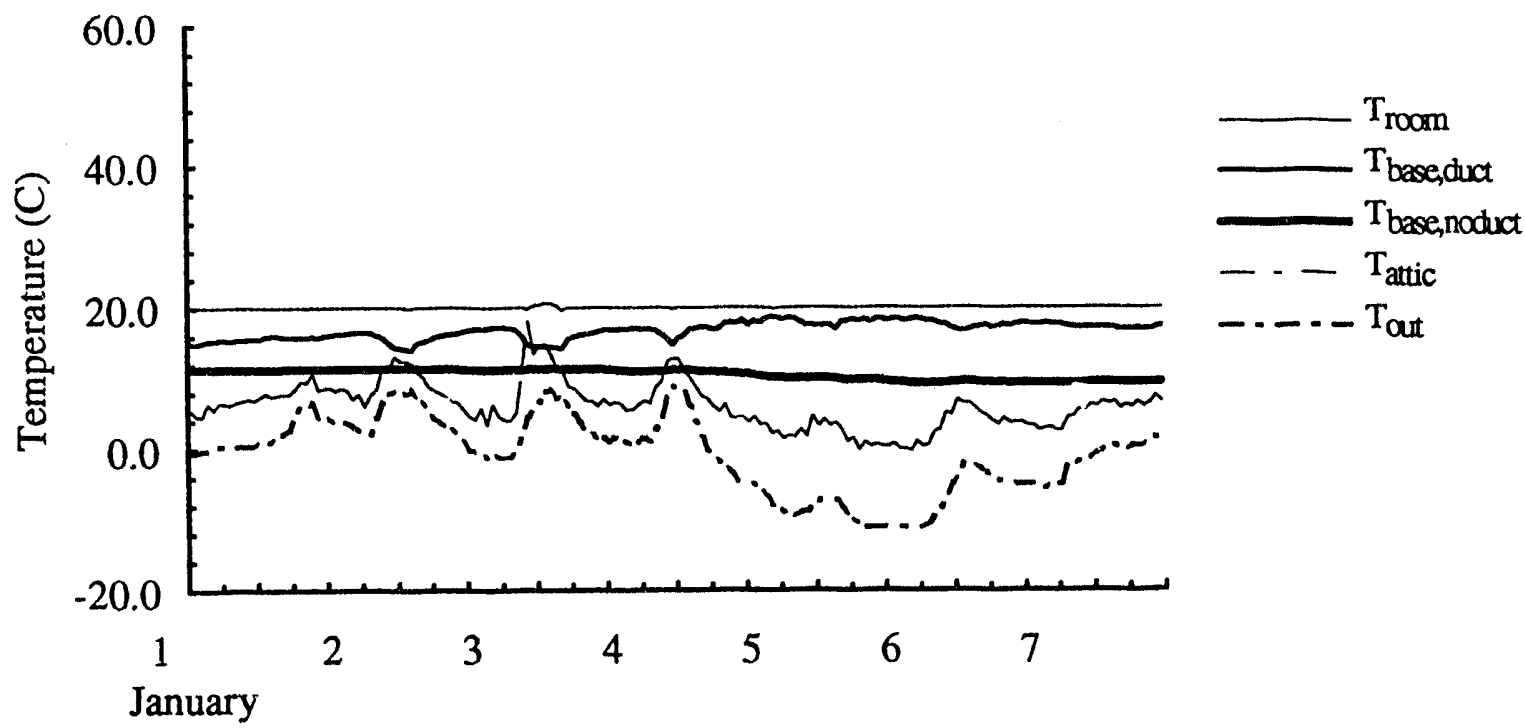

date

FIGURE 3. Zone temperatures for Washington with normal ducts for January 1-7.

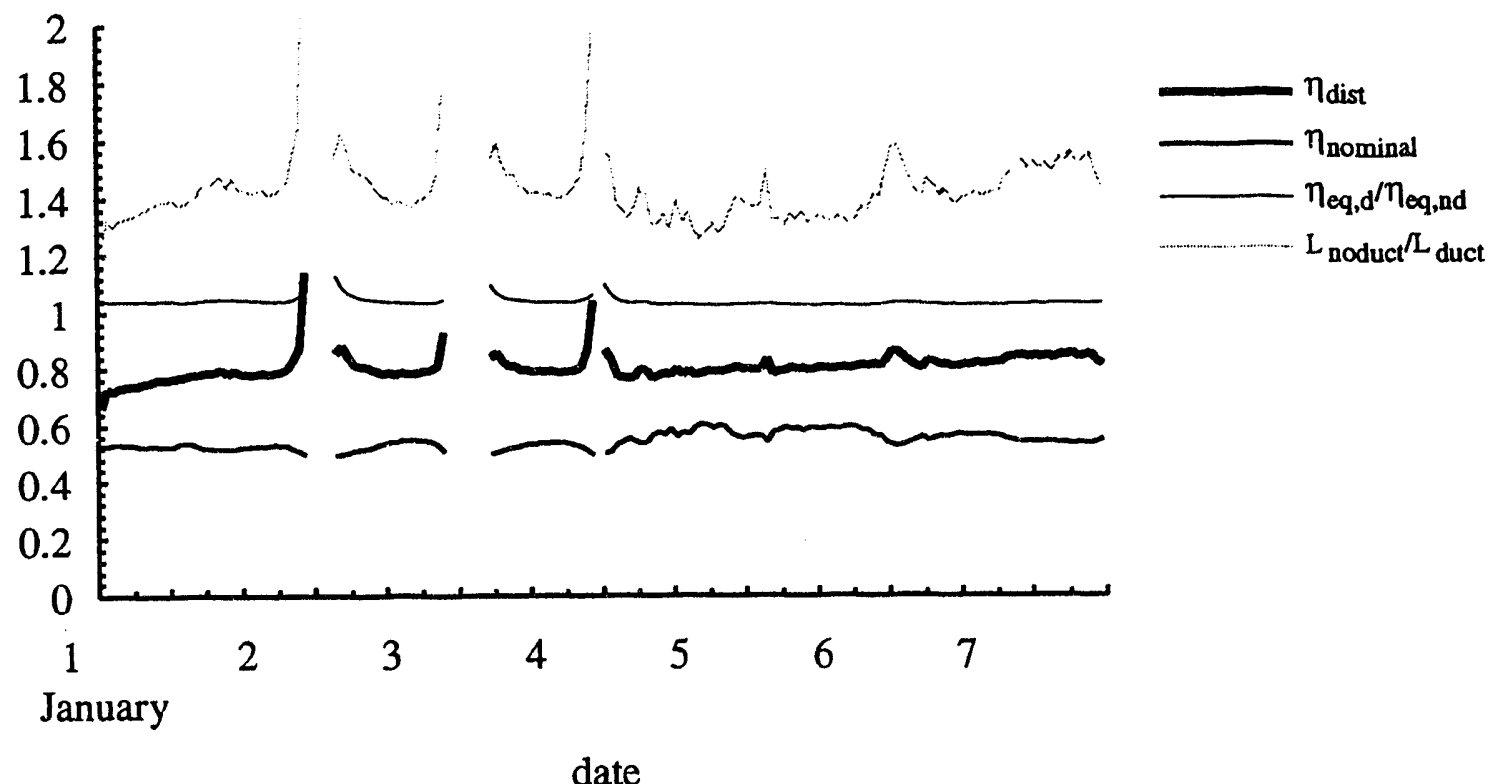

FIGURE 4. Quantities for $\eta_{\text {dist }}$ for Washington with normal ducts for January 1-7. 


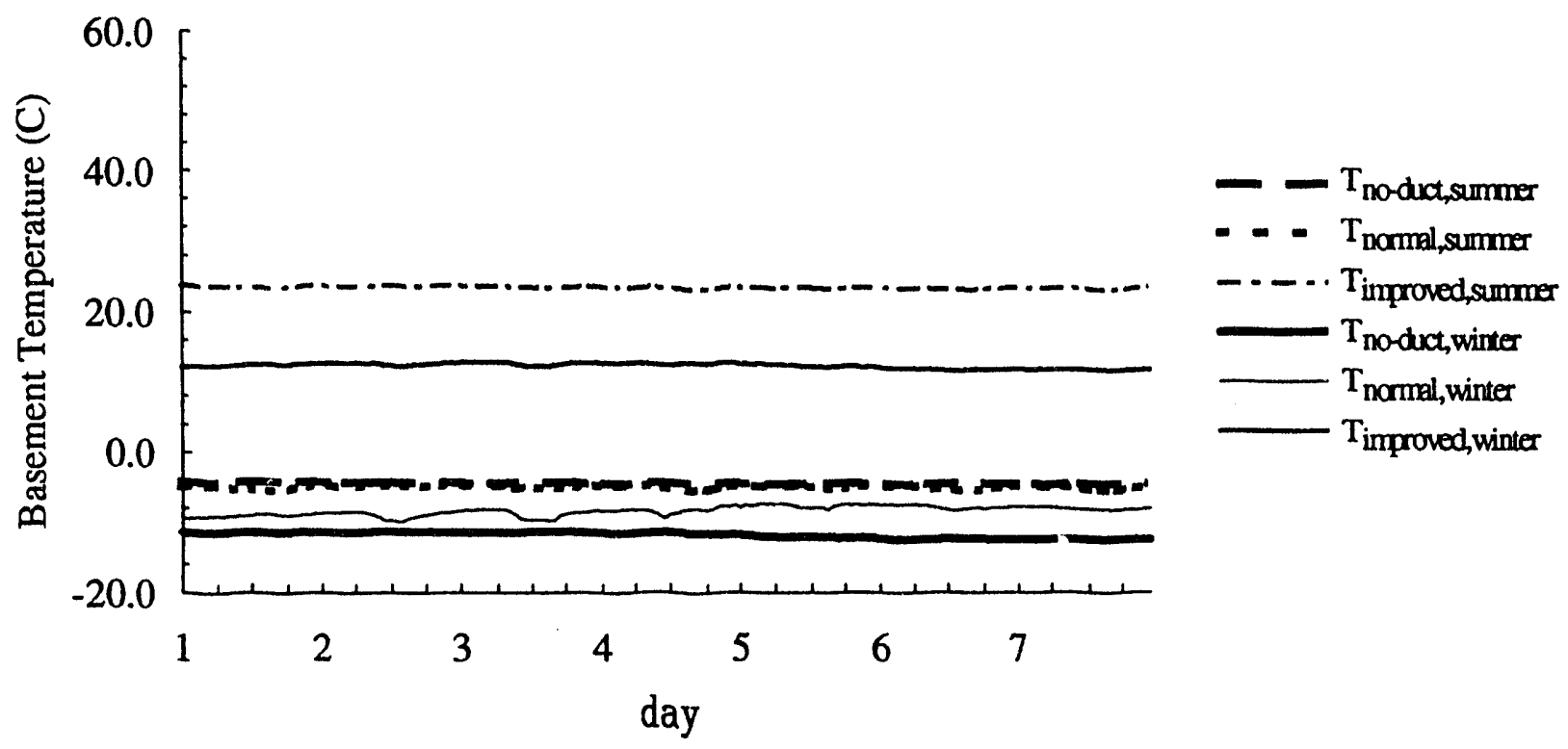

FIGURE 5. Comparison of $T_{\text {basemen }}$ between the no-duct, normal ducts, and improved duct cases for heating and cooling. The perfect duct case is not shown because $T_{\text {beseperfect }}=T_{\text {besenoduct }}$.

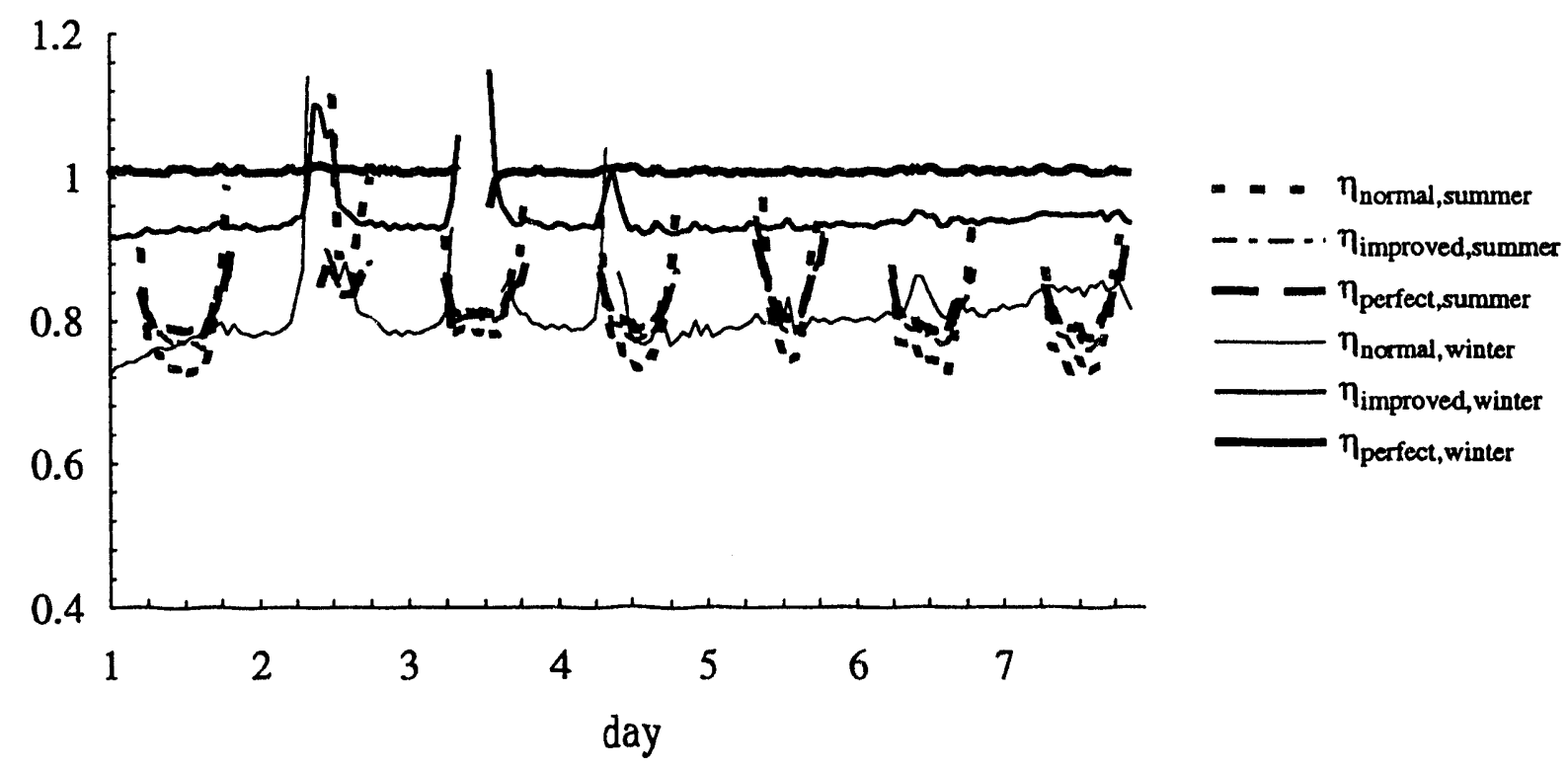

FIGURE 6. Comparison of $\eta_{\text {dist }}$ between the normal, improved, and perfect duct cases for heating and cooling. 


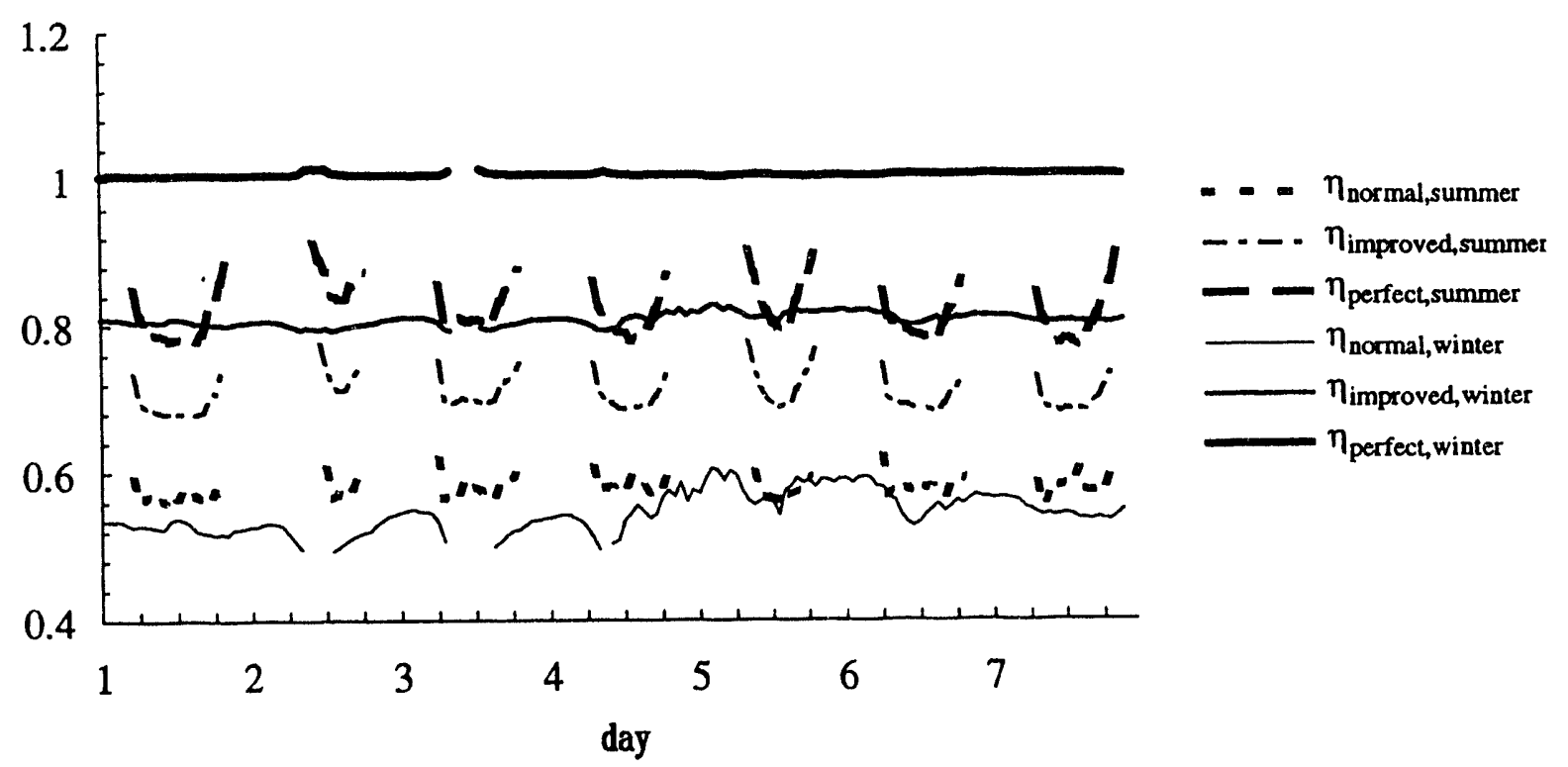

FIGURE 7. Comparison of $\eta_{\text {nominal }}$ between the normal, improved, and perfect duct cases for both beating and cooling.

Figures 5-7 present comparisons between the different duct conditions for $T_{\text {basement }}, \eta_{\text {dist }}$, and $\eta_{\text {nominal }}$, respectively. Results are presented for the Washington, D.C. house during both summer and winter. Figure 5 shows the basement temperature as a function of time for a week in summer and a week in winter. The main point to note is that $\mathrm{T}_{\text {basement }}$ for the normal duct case is up to $2.2^{\circ} \mathrm{C}$ cooler in the summer and $8^{\circ} \mathrm{C}$ warmer in the winter than when no ducts are present. Intuitively, it would be expected that temperatures for unconditioned zones will vary with $\mathrm{T}_{\text {out }}$. This is what happens in the no-duct case. However, the normal ducts lose so much energy to the basement that when $\mathrm{T}_{\text {out }}$ changes, $\mathrm{T}_{\text {base }}$ changes in the opposite direction because the system is on longer. The temperature differences are reduced to $0.8^{\circ} \mathrm{C}$ and $3^{\circ} \mathrm{C}$ for the improved duct case and the duct and no-duct basement temperatures vary in the same direction.

Figure 6 presents time series data for $\eta_{\text {dist }}$. In the winter, $\eta_{\text {dist }}$ approaches 1 as the duct system is improved. In the summer, $\eta_{\text {dist }}$ reaches a limit of about 0.8 because of the energy required to run the distribution system fan. For the winter results, insulating the ducts to R-5 and sealing lifts $\eta_{\text {dist }}$ from about 0.8 to greater than 0.9 . This represents an energy savings of more than $10 \%$. This is despite a much colder basement, as was shown in Figure 5. That the duct insulation and sealing level has little effect on the spurious peaks which occur during periods with low heating/cooling loads. 
Time series data for $\eta_{\text {nominal }}$ are shown in Figure 7. Again, efficiencies increase as the duct system is improved. As was explained before, these increases are larger than those for Figure 6 because $\eta_{\text {dist }}$ reflects the energy which is lost to the basement but still reaches the conditioned space.

\subsection{Conclusions}

The combination of the field measurements and simulation results presented in this study provides strong evidence that there is a significant potential for energy savings in typical basement houses.

Measurements of the specific envelope ELA's for 2 of the houses in this study showed they are $2-3 \mathrm{~cm}^{2} / \mathrm{m}^{2}$ of floor area. This is lower than was found in the California homes of Modera et al. (1991) for crawlspace homes. It is similar to the result found by Nelson et al. (1993) for new basement homes in Minnesota. The specific duct ELA was found to be about $2 \mathrm{~cm}^{2} / \mathrm{m}^{2}$ in this study. This is more than was found for California homes $\left(1 \mathrm{~cm}^{2} / \mathrm{m}^{2}\right)$ and less than found by Nelson et al. $\left(3 \mathrm{~cm}^{2} / \mathrm{m}^{2}\right)$.

The other important results from the field measurements involve air infiltration and duct conduction losses. Measurements of air infiltration showed that the leakage in the ducts produces significant infiltration loads since the infiltration increased by at least a factor of 2 . Conduction losses were found to between nine and thirty percent on mild days.

The field measurements showed a large potential for improving basement thermal distribution systems. The doubling of infiltration when the system fan was turned on insured this. However, the other field results are not as conclusive for energy savings. Leakage and conduction losses are primarily to the basement and some of that energy is recovered. Simulation results were needed to assess the importance of duct sealing and insulation. The field measurements served as guides to configuring the model house for leakage areas and insulation levels.

The simulation results confirmed that the leakiness and lack of insulation on the ducts was important despite the basement being a partly-conditioned space. The distribution system efficiency improved from 0.86 to 0.94 for a prototype house in Washington D.C. when the duct system leaks were reduced by $80 \%$ and the ducts in the basement were insulated to R-5. 10 percentage point improvements were found for prototype houses in Atlanta, GA and Minneapolis, MN. These efficiency improvements translate into $10 \%$ reductions of space conditioning energy use. For perfect ducts, which are heavily insulated and completely sealed, a reduction in energy use of $15 \%$ is attainable. Because the ELA of the ducts was set slightly lower than was found in the field studies, these savings are conservative estimates. 


\subsection{Acknowledgments}

The research reported here was supported by the Assistant Secretary for Conservation and Renewable Energy, Office of Buildings Technology, Building Equipment Division, of the U.S. Department of Energy under Contract No. DE-AC03-76SF00098.

\subsection{References}

ANSI/ASHRAE Standard 62-1989 (1990), American Society of Heating, Refrigerating, and Air-Conditioning Engineers, Inc., Atlanta, GA 30329.

ASTM E779-87 (1987), Determining Air Leakage Rate by Fan Pressurization, American Society for Testing and Materials, 1916 Race St., Philadelphia, PA 19103.

Birdsall, B., Buhl, W.F., Ellington, K.L., Erdem, A.E., Winkelmann, F.C. (1990), Overview of the DOE-2 Building Energy Analysis Program, Version 2.1, Lawrence Berkeley Laboratory Report, LBL-19735, Rev. 1, Berkeley CA.

BNL (1984), Plan for the conduct of research on residential thermal distribution and utilization, Architectural and Building Systems Division, Brookhaven National Laboratory, Upton NY.

Cummings, J.G.; Tooley, J.J. Jr. (1989), Infiltration and pressure differences induced by forced air systems in Florida residences, ASHRAE Trans. 96 (II).

DOE/EIA (1987), Housing Characteristics 1987, Washington D.C., Energy Information Administration, DOE/EIA-03(87), 69.

Feustel, H.E. and Raynor-Hoosen, A. (1990), Fundamentals of the Multizone Air Flow Model COMIS, Air Infiltration and Ventilations Center Technical Note, ATVC TN29, University of Warwick Science Park, Coventry, Great Britain.

Gammage, R.B., Hawthorne, A.R. and White, D.A. (1986), Parameters Affecting Air Infiltration and air tightness in 31 Tennessee homes, Measured Air Leakage of Buildings, ASTM STP 904, H.R. Trechsel and P.L. Lagus, Eds., 61-69, Philadelphia, American Society for Testing and Materials.

GEOMET, Inc., (1992), Evaluation of Residential Duct Systems in Basement Homes, Report No. IF-2598, July 10, 1992, GEOMET Technologies, Inc., 20251 Century Blvd., Germantown, $\mathrm{NiD} 20874$.

Grot, R.A., and Harrje, D.T. (1981), The transient performance of a forced warm air duct system, ASHRAE Trans. 88 (I).

Jacob, F.E., Locklin, D.W., Fischer, R.D., Flanigan, L.J., and Cudnik, R.A. (1986), SP43 Evaluation of System Options for Residential Forced-Air Heating, ASHRAE Trans., 92(II).

Jacob, F.E., Fischer, R.D., Flanigan, L.J., Locklin, D.W., Herold, K.E., and Cudnik, R.A. (1986a), Validation of the ASHRAE SP43 Dynamic Simulation Model for Residential Forced-Warm-Air Systems, ASHRAE Trans. 92 (II).

Locklin, D.W., Herold, K.E., Fischer, R.D., Jakob, F.E. and Cudnik, R.A. (1987), Supplemental Information from SP43 Evaluation of Systems Options for Residential Forced-Air Heating, ASHRAE Trans. 93 (II). 
Modera, M.P., Dickerhoff, D.J., Jansky R.E., and Smith, B.V. (1991), Improving the Energy Efficiency of Residential Air Distribution Systems in California - Final Report: Phase I, Lawrence Berkeley Laboratory Report, LBL-30886.

Modera, M.P., Andrews, J.A., and Kweller, E. (1992), A Comprehensive Yardstick for Residential Thermal Distribution Efficiency, ACEEE 1992 Summer Study Proceedings, Pacific Grove, California, August 30-September 5, 1992.

Modera, M.P., ond Jansky, R. (1992), Residential Air-Distribution Systems: Interactions with the Building Envelope, Proc. of ASHRAE-DOE-BTECC Thermal Performance of Buildings V, December.

Nelson, G., Nevitt, R., Moyer, N., and Tooley, J. (1993), Measured Duct Leakage, Mechanical System Induced Pressures and Infiltration in Eight Randomly Selected New Minnesota Houses, Proceedings of the Joint Conference of the Energy Efficient Building Association and the North East Sustainable Energy Association, Building Solutions Conference c/o Energy Efficient Building Association, 1000 Campus Dr., Wausau, WI 54401, pp. F-1 to F-12.

Orlando, J.A. and Gamze, M.G. (1980), Analysis of residential duct losses, Final Report, GRI-79/0037,Gamze-Korobkin-Caloger, Inc., Contract No. 5011-341-0156, Chicago.

Sherman, M.H., Wilson, D.J., and Kiel, D.E. (1984), Variability in Residential Air Leakage., Presented at ASTM symposium on Measured Air Leakage Performance of Buildings, Philadelphia, PA, April 2-3, 1984. 

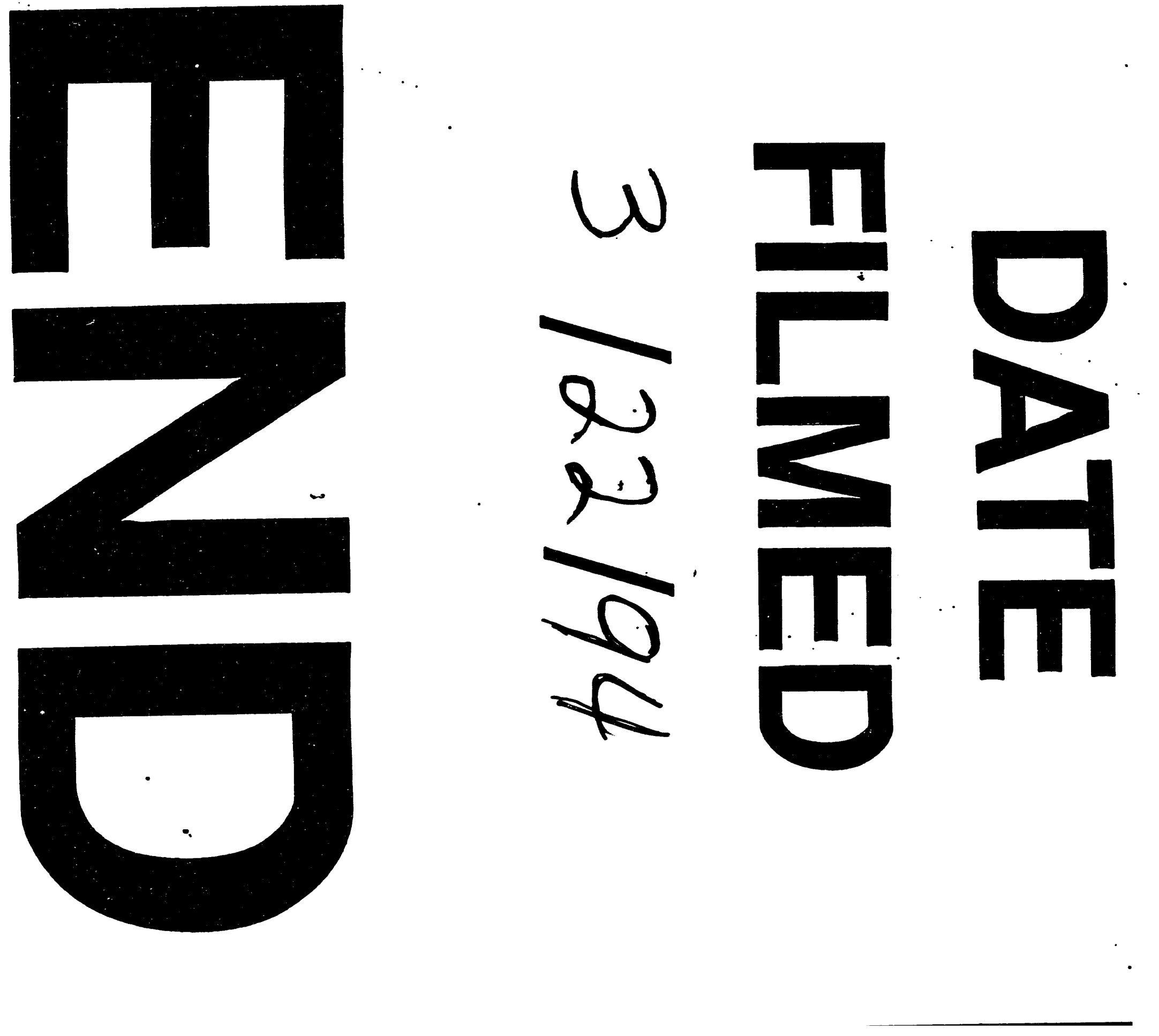


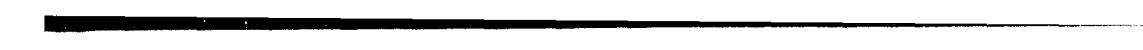

